\title{
Arginine decarboxylase: A novel biological target of mercury compounds identified in PC12 cells
}

\author{
Sufang Wang ${ }^{\mathrm{a}, \mathrm{c}}$, Qiyan Lv ${ }^{\mathrm{a}}$, Yu Yang ${ }^{\mathrm{a}, *}$, Liang-Hong Guo ${ }^{\mathrm{a}, \mathrm{b}, *}$, Bin Wan ${ }^{\mathrm{a}}$, Xiaomin Ren ${ }^{\mathrm{a}}$, Hui Zhang ${ }^{\mathrm{a}}$ \\ ${ }^{a}$ State Key Laboratory of Environmental Chemistry and Ecotoxicology, Research Center for Eco-Environmental Sciences, Chinese Academy of Sciences, P.O. Box 2871, 18 \\ Shuangqing Road, Beijing 100085, China \\ ${ }^{\mathrm{b}}$ Institute of Environment and Health, Jianghan University, Wuhan 430056, China \\ ${ }^{\mathrm{c}}$ College of Environmental Science and Engineering, Taiyuan University of Technology, Taiyuan 030024, China
}

\section{A R T I C L E I N F O}

\section{Article history:}

Received 15 July 2016

Accepted 22 August 2016

Available online 24 August 2016

\section{Keywords:}

Mercury

Neurotoxicity

Arginine decarboxylase

Inhibition

Molecular dynamics simulation

\begin{abstract}
A B S T R A C T
Mercury compounds are well-known toxic environmental pollutants and potently induce severe neurotoxicological effects in human and experimental animals. Previous studies showed that one of the mechanisms of mercury compounds neurotoxicity arose from the over-activation of the N-methyl D-aspartate (NMDA)-type glutamate receptor induced by increased glutamate release. In this work, we aimed to investigate the molecular mechanisms of $\mathrm{Hg}$ compounds neurotoxicities by identifying their biological targets in cells. Firstly, the inhibitory effects of four $\mathrm{Hg}$ compounds, including three organic (methyl-, ethyl- and phenyl-mercury) and one inorganic $\left(\mathrm{Hg}^{2+}\right) \mathrm{Hg}$ compounds, on the activity of arginine decarboxylase $(A D C)$, a key enzyme in the central agmatinergic system, were evaluated. They were found to inhibit the ADC activity significantly with methylmercury $(\mathrm{MeHg})$ being the strongest $\left(\mathrm{IC}_{50}=7.96 \mathrm{nM}\right)$. Furthermore, they showed remarkable inhibitory effects on ADC activity in PC12 cells $\left(\mathrm{MeHg}>\mathrm{EtHg}>\mathrm{PhHg}>\mathrm{HgCl}_{2}\right.$ ), and led to a marked loss in the level of agmatine, an endogenous neuromodulatory and neuroprotective agent that selectively blocks the activation of NMDA receptors. MeHg was detected in the immunoprecipitated ADC from the cells, providing unequivocal evidence for the direct binding of MeHg with ADC in the cell. Molecular dynamics simulation revealed that $\mathrm{Hg}$ compounds could form the coordination bond not only with cofactor PLP of ADC, but also with substrate arginine. Our finding indicated that MeHg could attenuate the neuroprotective effects of agmatine by the inhibition of $\mathrm{ADC}$, a new cellular target of $\mathrm{MeHg}$, which might be implicated in molecular mechanism of $\mathrm{MeHg}$ neurotoxicity.
\end{abstract}

(c) 2016 Elsevier Inc. All rights reserved.

\section{Introduction}

Mercury and its compounds are a kind of persistent toxic and bioaccumulative pollutant of global concern since their anthropogenic and natural emissions pose high risk to human and environmental health $[1,2]$. They are classified into three groups: elemental mercury, inorganic mercury such as mercuric chloride $\left(\mathrm{HgCl}_{2}\right)$, and organic mercury such as methylmercury ( $\mathrm{MeHg}$ ), ethylmercury (EtHg) and phenylmercury ( $\mathrm{PhHg}$ ). The main contribution to human exposure is the ingestion of fish and seafood ( $\mathrm{MeHg}$ ); also, it can occur from vaccines (EtHg), germicide and herbicide $(\mathrm{PhHg})$ and contaminated water and air $\left(\mathrm{HgCl}_{2}\right)$ [3]. They can accumulate in human organs, including brain, intestine,

\footnotetext{
* Corresponding authors at: State Key Laboratory of Environmental Chemistry and Ecotoxicology, Research Center for Eco-Environmental Sciences, Chinese Academy of Sciences, P.O. Box 2871, 18 Shuangqing Road, Beijing 100085, China (L.-H. Guo).

E-mail addresses: yuyang@rcees.ac.cn (Y. Yang), LHGuo@rcees.ac.cn (L.-H. Guo).
}

kidney, liver, and placenta [4]. Mercury compounds have shown a wide range of toxicological effects on human beings, involving especially the central nervous system (CNS) [5], causing damage to the brain, but also to the kidney [6], the cardiovascular [7], and immune systems [8]. The toxic properties of $\mathrm{Hg}$ compounds are directly related to the chemical forms of the element. Organic mercury is more efficiently absorbed into the body and subsequently more toxic than inorganic mercury. Elimination in the blood is slow with a half-life (in days) of 45-70 for MeHg, 5.68.8 for EtHg, 19.7-65.6 for inorganic $\mathrm{Hg}$, therefore allowing significant accumulation to occur [9-11]. Many studies show that high level of exposure to mercury induces changes in the CNS, potentially resulting in irritability, fatigue, behavioral changes, tremors, headaches, hearing and cognitive loss, dysarthria, incoordination, hallucinations, and death [12-14].

Among the mercury compounds, $\mathrm{MeHg}$ is primarily responsible for the neurological alterations present in humans and experimental animals. MeHg can be transported from the blood to the CNS 
across the blood-brain barrier as a cysteine complex by the L-type neutral amino acid carrier transport (LAT) system [15-17]. MeHg hampers the physiological increase in glutathione reductase (GR) and glutathione peroxidase (GPX) activities in the rodent CNS during the early postnatal period, but also decreases GPX activity in adult animals $[18,19]$. Glutamate dyshomeostasis in the CNS represents a critical mechanism in MeHg-induced neurotoxicity [20]. Glutamate is the major excitatory neurotransmitter in the mammalian CNS, where it plays key roles in development, learning, memory and response to injury. However, glutamate at high concentrations at the synaptic cleft acts as a toxin, inducing neuronal injury and death [21]. Increased glutamate concentration seems to depend, at least in part, on increased release and reduced astrocytic glutamate uptake, probably due to the inhibition of $\mathrm{Na}^{+} / \mathrm{K}^{+}$-ATPase activity by $\mathrm{MeHg}$ [22]. On the other hand, glutamate-mediated neurotoxicity has also been dubbed as "excitotoxicity", referring to the consequence of the over-activation of the N-methyl-D-aspartate (NMDA)-type glutamate receptor, partially contributes to increased $\mathrm{Ca}^{2+}$ influx into neurons [23]. Increased intracellular $\mathrm{Ca}^{2+}$ levels are associated with the generation of oxidative stress and neurotoxicity [24]. In addition, MeHg-induced disruption of intracellular calcium homeostasis is also independent of NMDA receptor activity in the presence of the NMDA receptor antagonist $\mathrm{D}$-2-amino-5-phosphonovaleric acid (APV) [25]. Although $\mathrm{Hg}$ compounds, especially $\mathrm{MeHg}$, have been extensively studied, the molecular mechanisms of $\mathrm{Hg}$ species mediated neurotoxicities remain not completely understood. Molecular targets of $\mathrm{Hg}$ species involved in neurotoxicities need to be explored.

Arginine decarboxylase (ADC) has been identified in the mammalian brain and other organs, such as the stomach, small intestine and aorta [26]. Agmatine is produced through decarboxylation of L-arginine by ADC. Agmatine, as a neurotransmitter in agmatinergic synapses of the CNS, is synthesized in both the brain and the spinal cord, stored in synaptic vesicles in heterogeneously distributed neurons and released from axon terminals by depolarization [27]. It binds with high affinity to $\alpha 2$-adrenergic receptors of all subclasses, imidazoline receptors of the I1 and I2 subclasses, enters several ionic conductance channels connected with ligandgated receptors, and selectively blocks the NMDA subclass of glutamate receptor [28-30]. Several studies have reported that agmatine exhibits neuroprotective action in both in vitro and in vivo animal models of neurotoxic and ischemic brain injuries [31]. Olmos et al. reported the neuroprotective effect of agmatine on glutamate-induced necrotic neuronal death in cultured cerebellar granule cells of rat pups. Agmatine could block NMDA receptor in rat hippocampal neurons by interacting with a site located within the NMDA channel pore [32]. Moreover, agmatine may reduce neurotoxicity induced by glucocorticoids through NMDAreceptor and calcium-channel blockade. Because neuronal death induced by glucocorticoids in the hippocampal area is related to mood disorders and neurodegenerative diseases, agmatine could protect hippocampal neurons from glucocorticoid-induced neuronal damage in clinical practice [33]. Agmatine is an agent that has nitric oxide synthase (NOS)-inhibitory and glutamateantagonistic activities in rodents [34]. Accumulating evidences suggest that both nitric oxide (NO) and glutamate contribute to hypoxia-ischemia central injury. It has been proved that agmatine has prominent neuroprotective effects on trauma- or ischemiainduced central injuries in animal models $[35,36]$. The abnormal release and transmission of agmatine in the brain may also be related to some CNS disorders. There are increasing number of preclinical studies demonstrating the neuromodulatory and neuroprotective properties of agmatine on depression, anxiety, hypoxic ischemia, nociception, morphine tolerance, memory, Parkinson's disease, Alzheimer's disease, traumatic brain injury related alterations/disorders and epilepsy [37]. These findings suggest that the central agmatinergic system may be a new important target for the development of therapeutic tools for diverse CNS disorders.

Considering the complexity of $\mathrm{Hg}$ compounds neurotoxicities, and the important role of ADC implicated in neuroprotective and neurorescue effects, we sought to find out if ADC would be a potential target of $\mathrm{Hg}$ compounds in neuron cells. We first employed a fluorescence sensing method to screen the inhibitory effects of four $\mathrm{Hg}$ compounds on ADC activity. The selected four $\mathrm{Hg}$ compounds, widely found in environmental media, are structurally diverse, with different functional groups. We then verified the inhibition and subsequent effects on agmatine biosynthesis in PC12 cells. To confirm that the biological effects in cells are derived from the interaction between $\mathrm{Hg}$ compound and ADC, we captured the $\mathrm{ADC}$ in cells by immunoprecipitation and detected the $\mathrm{Hg}$ compound associated with ADC. Besides, to explore the structural basis of inhibition difference, we performed molecular dynamics simulation and obtained the binding modes between the ADC and $\mathrm{Hg}$ species.

\section{Materials and methods}

\subsection{Reagents and instrumentation}

Arginine, agmatine, acridine orange (AO), cucurbit[7]uril (CB7), arginine decarboxylase (ADC, from Escherichia coli), difluoromethyl arginine (DFMA), pyridoxal 5'-phosphate (PLP), methylmercury chloride (MeHg), ethylmercury chloride (EtHg), phenylmercury chloride $(\mathrm{PhHg})$ and mercuric chloride $\left(\mathrm{HgCl}_{2}\right)$ were purchased from Sigma-Aldrich (St. Louis, MO, USA). Organic $\mathrm{Hg}$ compounds were dissolved in methanol and stored in dark at $4{ }^{\circ} \mathrm{C}$, respectively. Trizol was purchased from Invitrogen (Carlsbad, CA, USA). o-phthalaldehyde (OPA) was from TCI (Tokyo, Japan), and BCA protein assay kit was from Beyotime Institute of Biotechnology (Shanghai, China). HPLC grade acetonitrile and methanol were purchased from J.T Baker (Phillipsburg, NJ, USA). Sodium dodecyl sulfate (SDS), glycerol and 2-mercaptoethanol (ME) were acquired from Amresco (Cleveland, Ohio, USA). $\mathrm{NH}_{4} \mathrm{OAc}$, Tris- $\mathrm{HCl}, \mathrm{HCl}$ and $\mathrm{K}_{2} \mathrm{CO}_{3}$ were all obtained from Sinopharm Chemical Reagent Beijing Co. Ltd (Beijing, China). All reagents were of analytical reagent grade. Solutions were prepared in high-purity water from a Millipore milli-Q (Biocel) water purification system (Billerica, MA, USA). Fetal bovine serum (FBS), penicillin streptomycin, dulbecco's modified eagle medium (DMEM) were provided by Thermo Scientific (Waltham, MA, USA). Cell proliferation reagent WST-1 was purchased from Roche Applied Science Inc (Basel, Switzerland). RevertAid first strand cDNA synthesis Kit was obtained from Thermo Scientific (Waltham, MA, USA). GoTaq ${ }^{\circledR}$ qPCR master mix kit was from Promega (Madison, WI, USA), and anti-ADC antibody produced in rat was obtained from Abnova (Taiwan, China). PCR instrument (GeneAmp ${ }^{\circledR}$ PCR System 9700), ELISA plate reader Varioskan Flash (Thermo, Waltham, MA, USA), real-time fluorescence quantitative PCR instrument Mx3005P (Agilent, Santa Clara, CA, USA), vertical electrophoresis instrument (Bio-Rad, Hercules, CA, USA). Steady-state fluorescence was measured on a Horiba Fluoromax-4 spectrofluorimeter (Edison, NJ, USA).

\subsection{Fluorescence enzyme activity assay}

In our work, a self-assembled host-guest inclusion complex was employed as a fluorescence sensor for the assay of ADC activity. The complex was composed of macrocyclic host cucurbit[7]uril (CB7) and fluorescent dye acridine orange (AO). Competitive binding of enzyme product agmatine with $\mathrm{CB} 7$ displaces $A O$ from $C B 7$, 
leading to reduced fluorescence signal. If ADC activity is inhibited, the fluorescence intensity would remain unchanged. The excitation and emission wavelengths were $485 \mathrm{~nm}$ and $510 \mathrm{~nm}$, respectively. Excitation and emission slits were all set at $3 \mathrm{~nm}$.

First of all, the binding interaction of AO with $\mathrm{CB} 7$ was investigated by successive addition of a known amount of $C B 7$ into $0.5 \mu \mathrm{M}$ AO solution. With the optimized CB7/AO concentration, fluorescence displacement measurements were carried out to examine the binding affinity of arginine (ADC substrate) and agmatine (ADC product) with CB7. It was performed by successive addition of a known amount of arginine or agmatine into a mixed solution of $0.5 \mu \mathrm{M} \mathrm{AO}$ and $5 \mu \mathrm{M}$ CB7. In the ADC activity assay, an ADC stock solution was prepared by dissolving $500 \mu \mathrm{g}$ solid in $1 \mathrm{~mL} \mathrm{HCl}-$ $\mathrm{NH}_{4} \mathrm{OAc}$ buffer ( $10 \mathrm{mM}$, pH 6.0). Enzyme reaction was performed in an Eppendorf tube containing a $100 \mu \mathrm{L}$ solution of $1.2 \mu \mathrm{g} \mathrm{mL}^{-1}$ ADC, $20 \mu \mathrm{M}$ arginine, $0.5 \mu \mathrm{M} \mathrm{AO}$, and $5 \mu \mathrm{M} \mathrm{CB} 7$, and the temperature was thermostatically controlled at $37.0 \pm 0.1^{\circ} \mathrm{C}$. The reaction was monitored by recording AO fluorescence emission spectrum with time. For the ADC inhibition assay, $1.2 \mu \mathrm{g} \mathrm{mL}^{-1} \mathrm{ADC}$ and different concentrations of inhibitor ( $\mathrm{Hg}$ compounds or DFMA) were mixed in $\mathrm{HCl}-\mathrm{NH}_{4} \mathrm{OAc}$ buffer $(\mathrm{pH}$ 6.0) and incubated at $37.0 \pm 0.1{ }^{\circ} \mathrm{C}$ for $15 \mathrm{~min}$ ( $\mathrm{Hg}$ compounds) or $5 \mathrm{~h}$ (DFMA). Then, $0.5 \mu \mathrm{M}$ AO, $5 \mu \mathrm{M} \mathrm{CB} 7$ and $20 \mu \mathrm{M}$ arginine were added. Fluorescence spectra were recorded after reacting for $1.5 \mathrm{~h}$. The change of fluorescence intensity $v s$ time was taken as a relative reaction rate, and was plotted as a function of inhibitor concentration. The dose-response curves were fitted with a sigmoidal model (Origin Lab 8.0, Northampton, MA, USA) and analyzed with the Hill equation to obtain $\mathrm{IC}_{50}$ values.

\subsection{Cell culture and treatment}

The rattus norvegicus PC12 cell line was purchased from ATCC (Manassas, VA, USA) and maintained in complete DMEM contain- ing $6 \%$ heat-deactivated fetal bovine serum (GIBCO, Invitrogen Life Technology, New York, CA, USA), 6\% horse serum, penicillin and streptomycin ( $100 \mathrm{U} \mathrm{mL}^{-1}$ each). Cells within 20 passages were used for experiments and cultured at $37^{\circ} \mathrm{C}$ in a humidified atmosphere of $95 \%$ air and $5 \% \mathrm{CO}_{2}$. Cells were seeded at approximated $0.5-1 \times 10^{5}$ cells $\mathrm{mL}^{-1}$ in 96 -well plates for cell viability assay, and 6-well plates for RNA isolation and protein collection. The exposure was performed in DMEM with or without (aqueous solution containing $10 \%$ pluronic f68 control) $\mathrm{MeHg} / \mathrm{EtHg}$ (up to $50 \mu \mathrm{M}$ ), and $30 \mu \mathrm{M}$ for $\mathrm{PhHg}$, respectively. The exposure lasted for $24 \mathrm{~h}$ unless specified elsewhere.

\subsection{Cell viability assay}

The viability changes of the cells under $24 \mathrm{~h}$ exposure of $\mathrm{Hg}$ compounds at various concentrations were determined by using cell proliferation reagent WST-1 (Roche Applied Science, Penzberg, Germany), according to the protocol provided by the manufacturer. In brief, after the exposure, WST-1 reagent (1:10 dilution) was added into each well of the 96-plate, followed by $4 \mathrm{~h}$ incubation at $37^{\circ} \mathrm{C}$. The absorbance data were then recorded on a Varioskan Flash microplate reader (Thermo Fisher Scientific, Waltham, MA, USA) at $440 \mathrm{~nm}$ and the absorbance at $600 \mathrm{~nm}$ was used as reference.

\subsection{Total RNA isolation and gene expression analysis}

Total RNA was extracted from cells exposed to $\mathrm{Hg}$ compounds using Trizol reagent according to the manufacturer's instruction. The quality and quantity of the purified total RNA were assessed by Nanodrop 1000 spectrophotometer (Thermo, Waltham, MA, USA). The gene expression of ADC was analyzed by using realtime reverse-transcriptase polymerase chain reaction (RT-PCR). First, total RNA was converted to first-strand cDNA with reverse
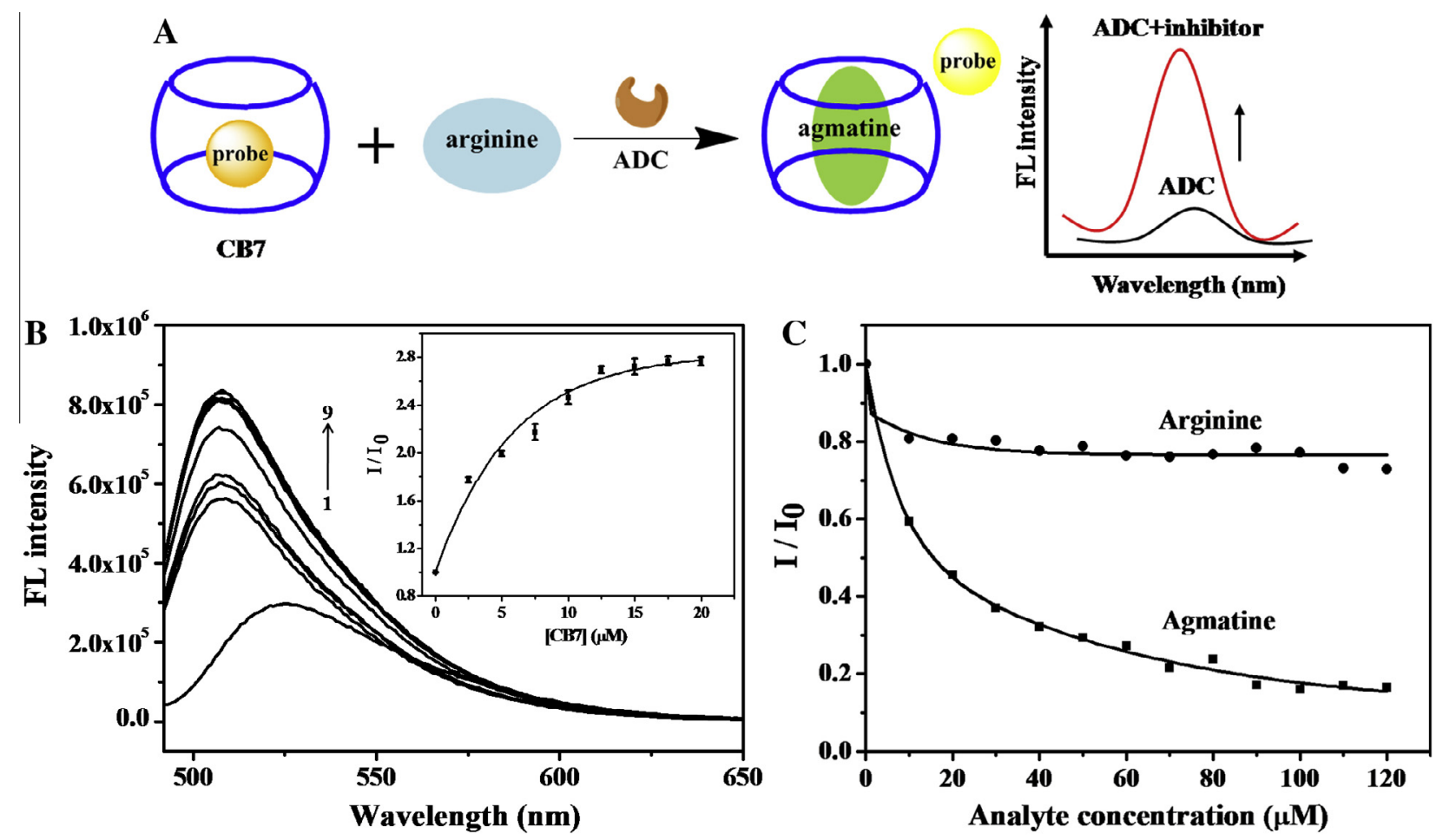

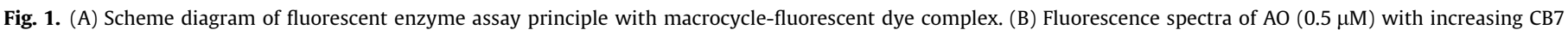

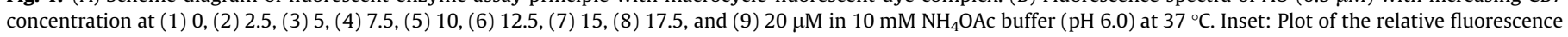

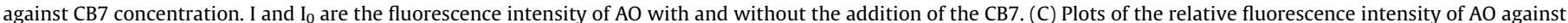

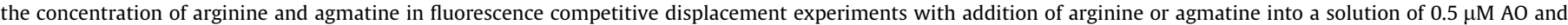

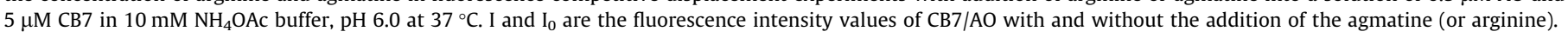


transcription using oligo(dT)18 primer. Quantitative PCR (QPCR) was then performed using the GoTaq ${ }^{\circledR}$ qPCR master mix kit. The assay was performed in triplicates on a real-time QPCR system. The sequences of PCR primers used were as follows: ADC Left: 5'TGG GTG CTG TAG TGA GGA AG-3'; Right: 5'-AAC TCC ATC TCT GCC TTG CT-3'; $\beta$-actin Left: $5^{\prime}$-TTG CCC TAG ACT TCG AGC AA3'; Right: 5'-CAG GAA GGA AGG CTG GAA GA-3'. PCR reaction was performed as follows: $2 \mathrm{~min}$ at $95^{\circ} \mathrm{C}$ followed by $15 \mathrm{~s}$ at $95^{\circ} \mathrm{C}, 50 \mathrm{~s}$ at $60^{\circ} \mathrm{C}$ and $45 \mathrm{~s}$ at $72^{\circ} \mathrm{C}$ for 40 cycles, then $7 \mathrm{~min}$ extension at $72{ }^{\circ} \mathrm{C}$. The cycle threshold $(\mathrm{Ct})$ for each sample was generated automatically by the MxPro software (Strategene, La Jolla, CA, USA). The Ct value for each sample corresponds to the point at which the fluorescence crosses the threshold. After PCR, melting curve analysis was performed and the PCR products were visualized using gel electrophoresis to assess the specificity of PCR amplification reactions. The house keeping gene, $\beta$-actin was used as an endogenous control. The ratio of gene expression between control and treatment groups was calculated by using the $2-\Delta \Delta \mathrm{CT}$ method.

\subsection{Western blot}

The exposed cells were lysed with RIPA lysis buffer (containing $4 \%$ SDS, $20 \%$ glycerol and $2 \% \mathrm{ME}$ ) and the protein concentration of each sample was determined by BCA protein assay kit according to the manufacturer's instructions. The samples were separated by SDS-PAGE gel electrophoresis and then transferred to a PVDF membrane $(0.45 \mu \mathrm{m})$. The membranes were blocked in $5 \%$ nonfat
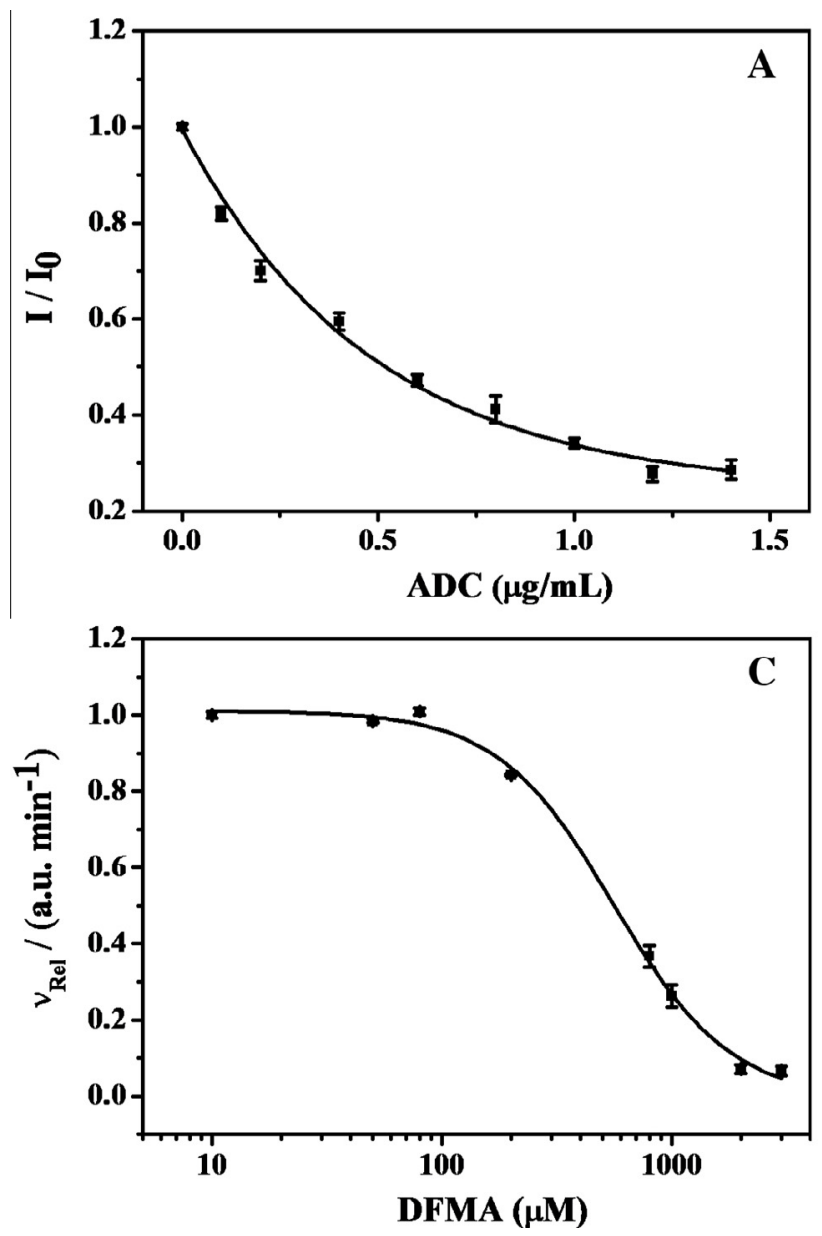

milk and washed in TBST (containing 0.1\% Tween 20), followed by incubation with primary antibodies (1:300 dilution) specific for ADC (Santa Cruz biotechnology, Dallas, Texas, USA) and $\beta$ actin (Cell Signaling Technology, Danvers, MA, USA) at $4{ }^{\circ} \mathrm{C}$ overnight. The corresponding HRP-conjugated secondary antibodies (1:5000 dilutions) were incubated with the membranes for $1 \mathrm{~h}$ at room temperature, followed by TBST wash. The last step was Xray film exposure.

\subsection{ADC activity assay in cells}

To further verify the effects of $\mathrm{Hg}$ compounds on ADC enzymatic activity in living cells, changes in ADC activity in PC12 cell after $\mathrm{Hg}$ exposures were investigated by high-performance liquid chromatography (HPLC). ADC activity assay mixtures $(2 \mathrm{~mL})$ contained $50 \mathrm{mM}$ Tris- $\mathrm{HCl}$ ( $\mathrm{pH} 7.5$ ), $4 \mathrm{mM} \mathrm{MgSO}_{4}, 1 \mathrm{mM}$ pyridoxal 5'-phosphate (PLP), $0.1 \mathrm{mM}$ dithiothreitol, and $10 \mathrm{mM}$ L-arginine. Reactions were initiated by the addition of $200 \mu \mathrm{L}$ of cell lysate and incubated for $15 \mathrm{~min}$ at $40{ }^{\circ} \mathrm{C}$. Reactions were stopped with the addition of $1 / 5$ volume of $40 \%$ trichloroacetic acid. The concentration of the agmatine product was determined by HPLC as described previously $[38,39]$.

\subsection{Variations of agmatine level in exposed cells}

We detected the agmatine levels in control and exposed cell by HPLC method. After $24 \mathrm{~h}$ exposure, cells were lysed in buffer and separated by centrifuging the tubes at $8000 \mathrm{~g}$ for $20 \mathrm{~min}$. HPLC
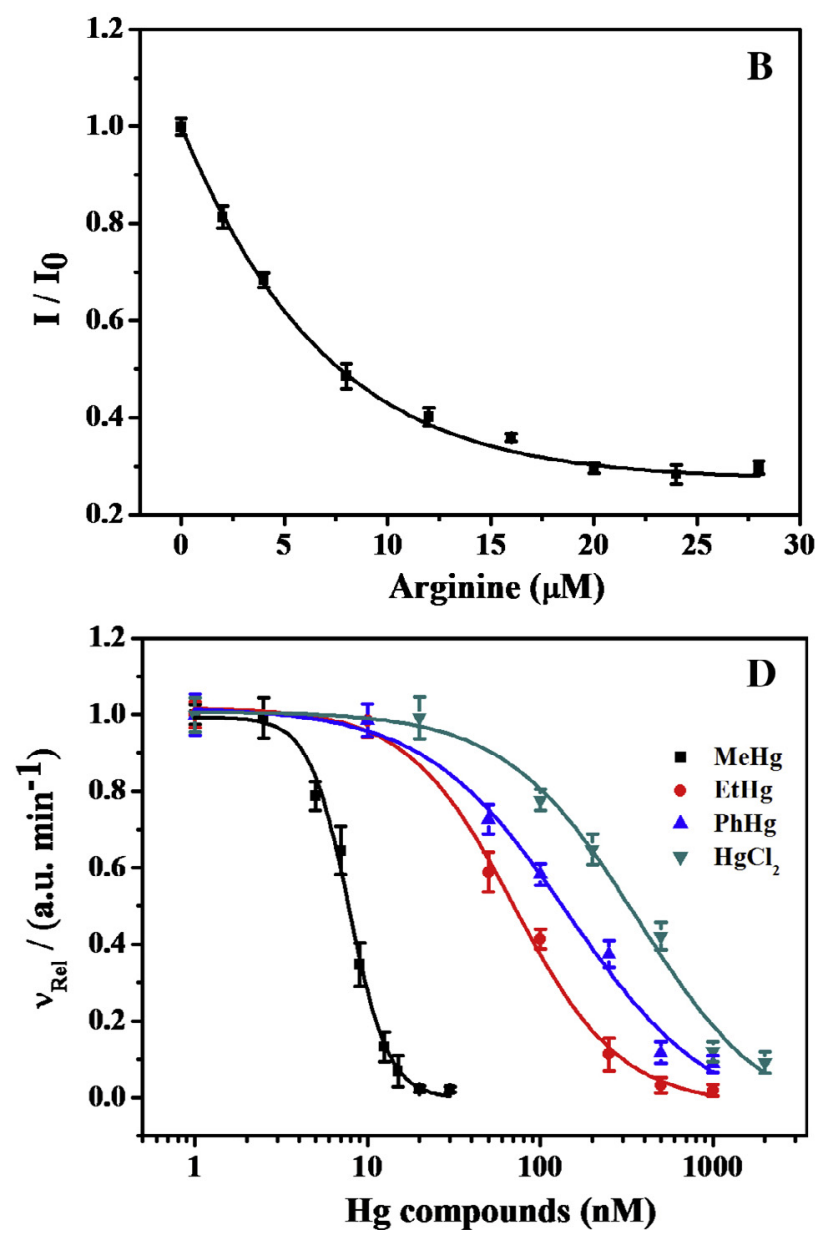

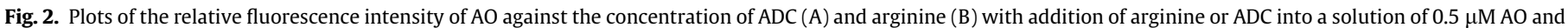

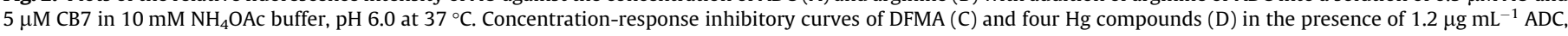
$20 \mu \mathrm{M}$ arginine, $0.5 \mu \mathrm{M} \mathrm{AO}$ and $5 \mu \mathrm{M}$ CB7 in $10 \mathrm{mM} \mathrm{NH}_{4} \mathrm{OAc}$ buffer, pH 6.0 at $37^{\circ} \mathrm{C}$. 
analysis of agmatine was performed by automatic pre-column derivatization with o-phthalaldehyde (OPA) and separated on an Acclaim $120 \mathrm{C} 18$ column $(250 \mathrm{~mm} \times 4.6 \mathrm{~mm} \times 5 \mu \mathrm{m})$. Fluorescent derivatives were detected by excitation at $330 \mathrm{~nm}$ and emission at $465 \mathrm{~nm}$. Samples $(8 \mu \mathrm{L})$ were mixed with $4 \mu \mathrm{L}$ of OPA derivatization reagent ( $30 \mathrm{mg}$ OPA in $1 \mathrm{~mL}$ methanol, $53 \mu \mathrm{L} \mathrm{ME}$ and $9 \mathrm{~mL}$ $0.5 \mathrm{M}$ potassium borate buffer $\mathrm{pH} 9.2$ ) and stored at $-20^{\circ} \mathrm{C}$. The polar eluent was $10 \mathrm{mM} \mathrm{KH}_{2} \mathrm{PO}_{4}$ pH 5.3 (buffer A), and the nonpolar eluent was a 5:3:1 (v/v/v) mixture of acetonitrile, methanol and

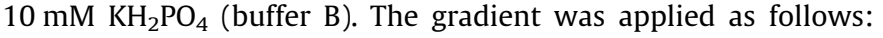
0 min $80 \%$ A, 4 min $73 \%$ A, 8 min $50 \%$ A, 12 min 30\% A, 16 min $25 \%$ A, 20 min 20\% A, 24 min 40\% A, 28 min 60\% A, 32 min 80\% A.

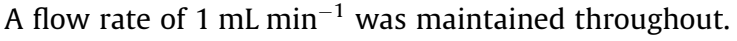

\subsection{Immunoprecipitation and analysis of $\mathrm{MeHg}$}

Tosylated superparamagnetic beads (Dynabeads, $2.8 \mu \mathrm{m}$ ) were conjugated with anti-ADC antibody as follows: $200 \mu \mathrm{g}$ antibody with $5 \mathrm{mg}$ Dynabeads in $0.1 \mathrm{M}$ borate buffer $(\mathrm{pH} 8.5)$ and $3.0 \mathrm{M}$
$\left(\mathrm{NH}_{4}\right)_{2} \mathrm{SO}_{4}$ buffer (pH 8.5) for $18 \mathrm{~h}$ at $37^{\circ} \mathrm{C}$. Dynabeads conjugated with an irrelevant IgG (Guinea pig IgG) or ethanolamine was used as control group. After that, the beads were blocked with excess ethanolamine and then resuspended in pre-cold PBS. The PC12 cells were exposed to $\mathrm{MeHg}(5 \mu \mathrm{M})$ for $24 \mathrm{~h}$, or with aqueous solution containing $10 \%$ pluronic f6 8 as vehicle control. After exposure, all cells were washed twice with ice-cold PBS, and total cellular proteins were collected by lysing the cells with RIPA buffer. The concentration of each protein sample was measured with a BCA protein assay kit. Then, $0.8 \mathrm{mg}$ Dynabeads with different surface modification abovementioned were added to cell lysate containing $8 \mathrm{mg}$ protein to immunoprecipitate for $6 \mathrm{~h}$ at $4{ }^{\circ} \mathrm{C}$, respectively. After magnetic separation, Dynabeads were washed four times with ice-cold PBS and then pretreated using the $\mathrm{KBr} / \mathrm{CuSO}_{4}$ extraction and $\mathrm{CH}_{2} \mathrm{Cl}_{2}$ reversed extraction method to capture the $\mathrm{MeHg}$ on them [40]. In brief, the $\mathrm{KBr}(18 \%, \mathrm{~m} / \mathrm{V}) / \mathrm{CuSO}_{4}(1.0 \mathrm{M})$ solution (volume ratio, 3:1) was added to a $15 \mathrm{~mL}$ polypropylene (PP) tube containing different Dynabeads, respectively. The mixture was shaken for $4 \mathrm{~h}$ at $240 \mathrm{rpm}$ and extracted by $\mathrm{CH}_{2} \mathrm{Cl}_{2}$ with shaking

Table 1

$\mathrm{IC}_{50}$, and some molecular dynamics simulation results of $\mathrm{Hg}$ compounds.

\begin{tabular}{|c|c|c|c|c|c|c|c|}
\hline \multirow[t]{2}{*}{ Hg compounds } & \multirow[t]{2}{*}{$\mathrm{IC}_{50}(\mathrm{nM})$} & \multirow[t]{2}{*}{ Binding energy (kcal/M) } & \multicolumn{2}{|l|}{ Binding sites } & \multirow[t]{2}{*}{ Distance ( $\mathrm{A})$} & \multicolumn{2}{|c|}{$\begin{array}{l}\text { Angle } \\
\text { (degree) }\end{array}$} \\
\hline & & & One & Another & & $\alpha$ & $\beta$ \\
\hline $\mathrm{MeHg}$ & 7.96 & $-951.19 \pm 193.04$ & O1, 02 and 03 of PLP & & $2.2-2.6$ & 109 & 90 \\
\hline EtHg & 70.34 & $-750.48 \pm 173.28$ & 01 and 02 of PLP & & $2.2-2.8$ & - & - \\
\hline $\mathrm{PhHg}$ & 145.03 & $-664.45 \pm 116.55$ & 01, 02 and 03 of PLP & & $2.2-2.6$ & 109 & 100 \\
\hline $\mathrm{HgCl}_{2}$ & 364.71 & - & $\mathrm{O} 1, \mathrm{O} 2$ and $\mathrm{O} 3$ of PLP & SH group of Cys254 in ADC & - & - & - \\
\hline
\end{tabular}
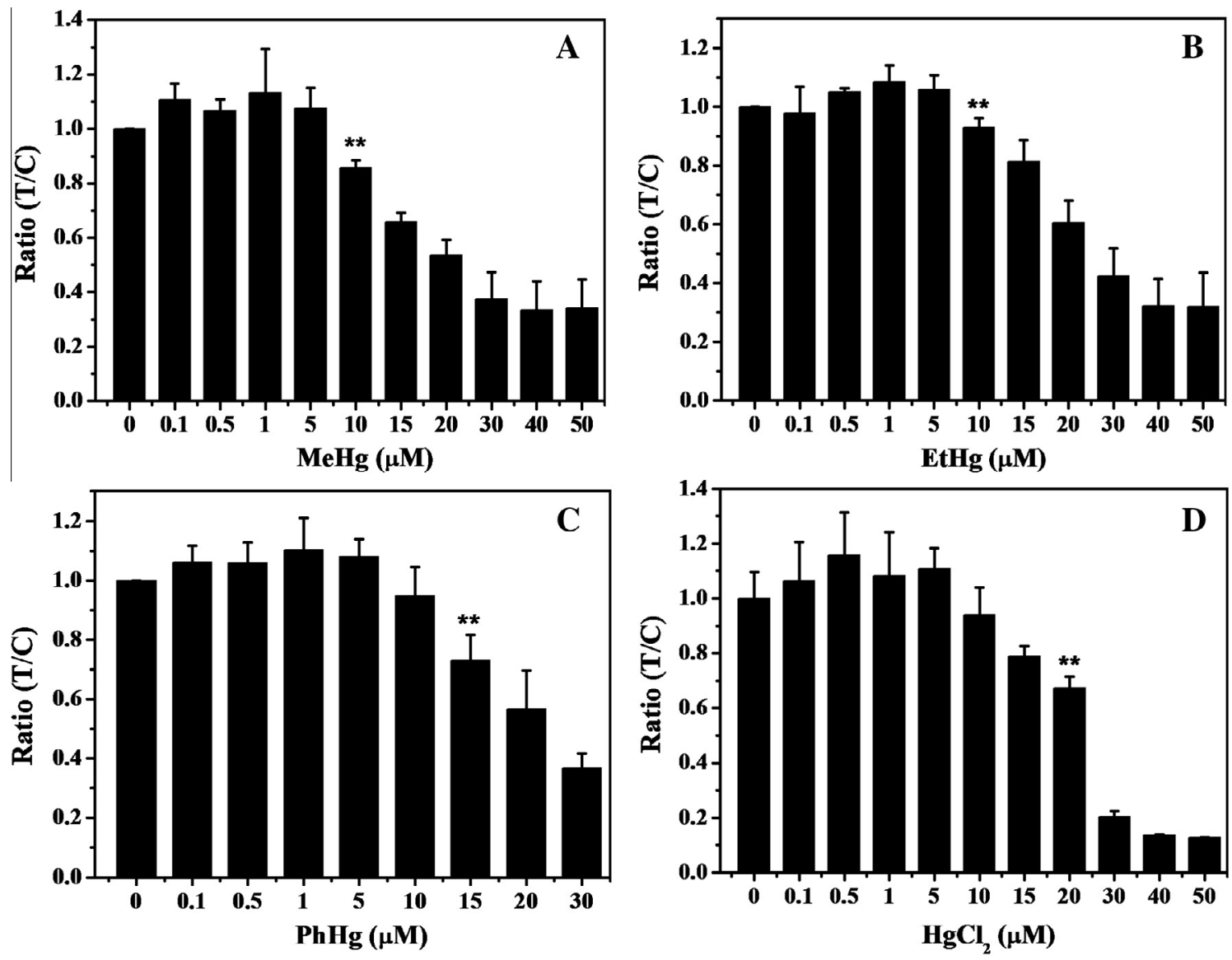

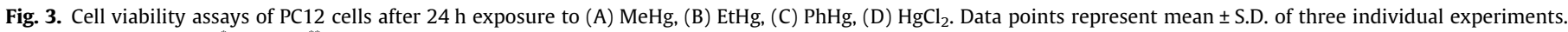
Significance was set as ${ }^{*} \mathrm{p}<0.05,{ }^{* *} \mathrm{p}<0.01$. 
$1 \mathrm{~h}$ at $240 \mathrm{rpm}$. Then, the sample of organic phase was reversely extracted using $0.01 \mathrm{M} \mathrm{Na}_{2} \mathrm{~S}_{2} \mathrm{O}_{3}$ solution. Analysis of $\mathrm{MeHg}$ was performed using gas chromatography (Methyl-Hg GC \& Pyrolysis, Brooks Rand, Seattle, WA, USA) coupled with atomic fluorescence spectrophotometer (AFS, Model III, Brooks Rand, Seattle, WA, USA).

\subsection{Molecular dynamics simulation}

The force field and parameter for $\mathrm{Hg}$ compounds to be used in our molecular dynamics simulation was developed by Gamess. The geometries of the Organic-Hg were optimized at the HartreeFock level, using the LANL2D and $6-31 G^{* *}$ basis. Hydrogen atoms of the protein residues were added using tLeaP. The system was centered in a cubic box of TIP3P water molecules. A sufficient number of $\mathrm{Na}^{+}$ions were added to neutralize the negative charges in the system. ff99SB force field was used to assign protein, with General Amber Force Field (GAFF) parameterized for substrate. The classical molecular dynamics simulation was performed using NAMD2.9 software package. The system was first minimized by 5000 steps of steepest and 5000 steps of conjugate gradient. Then the system was heated to the target temperature of $300 \mathrm{~K}$ for a period of $20 \mathrm{ps}$ in constant pressure periodic boundary conditions (NPT). The system was subjected to equilibrate the system by 10 ns of constant pressure and temperature (NPT) with time step of $1 \mathrm{fs}$, which was followed by $90 \mathrm{~ns}$ of production simulation performed in the same conditions. A cutoff of $10 \AA$ was used for nonbonded interactions and long-range electrostatic interactions were treated by means of the Particle Mesh Ewald (PME) method. The molecular dynamics simulation results were analyzed using the Cpptraj program in the AmberTools 14 package and Pymol.

\section{Results}

3.1. Inhibition of ADC activity by $\mathrm{Hg}$ compounds using a fluorescent enzyme assay

To investigate the inhibitory effects of $\mathrm{Hg}$ compounds on ADC, a proper enzyme activity assay is needed. In 2007, Henning et al. described a novel concept for the determination of enzyme activity of $A D C$, using macrocyclic receptors and fluorescent dyes such as CB7/Dapoxyl and CX4/DBO [41]. This product-competitive displacement method is simple, convenient and label-free (Fig. 1A). We optimized the reporter pair (Fig. 1B) and used CB7/AO $(5 \mu \mathrm{M} / 0.5 \mu \mathrm{M})$ to determine the inhibitory effects of $\mathrm{Hg}$ compounds on ADC activity. In the fluorescence sensing assay, substrate and product exhibited differential capability in displacing AO from CB7 and thereby changing the fluorescence signal (Fig. 1C). The relative fluorescence intensity at $510 \mathrm{~nm}$ was plotted as a function of the competitor concentration. The association constants of CB7 with arginine and agmatine were estimated to be $6.03 \times 10^{2} \mathrm{M}^{-1}$ and $8.94 \times 10^{5} \mathrm{M}^{-1}$, which were in good agreement with previous reports, $3.10 \times 10^{2} \mathrm{M}^{-1}$ for arginine and $1.10 \times 10^{6} \mathrm{M}^{-1}$ for agmatine [41]. Obviously, agmatine has much higher affinity with $\mathrm{CB} 7$ than arginine. Then, a CB7/AO system for real-time monitoring of ADC activity was established. The optimal concentrations of ADC and arginine were determined to be
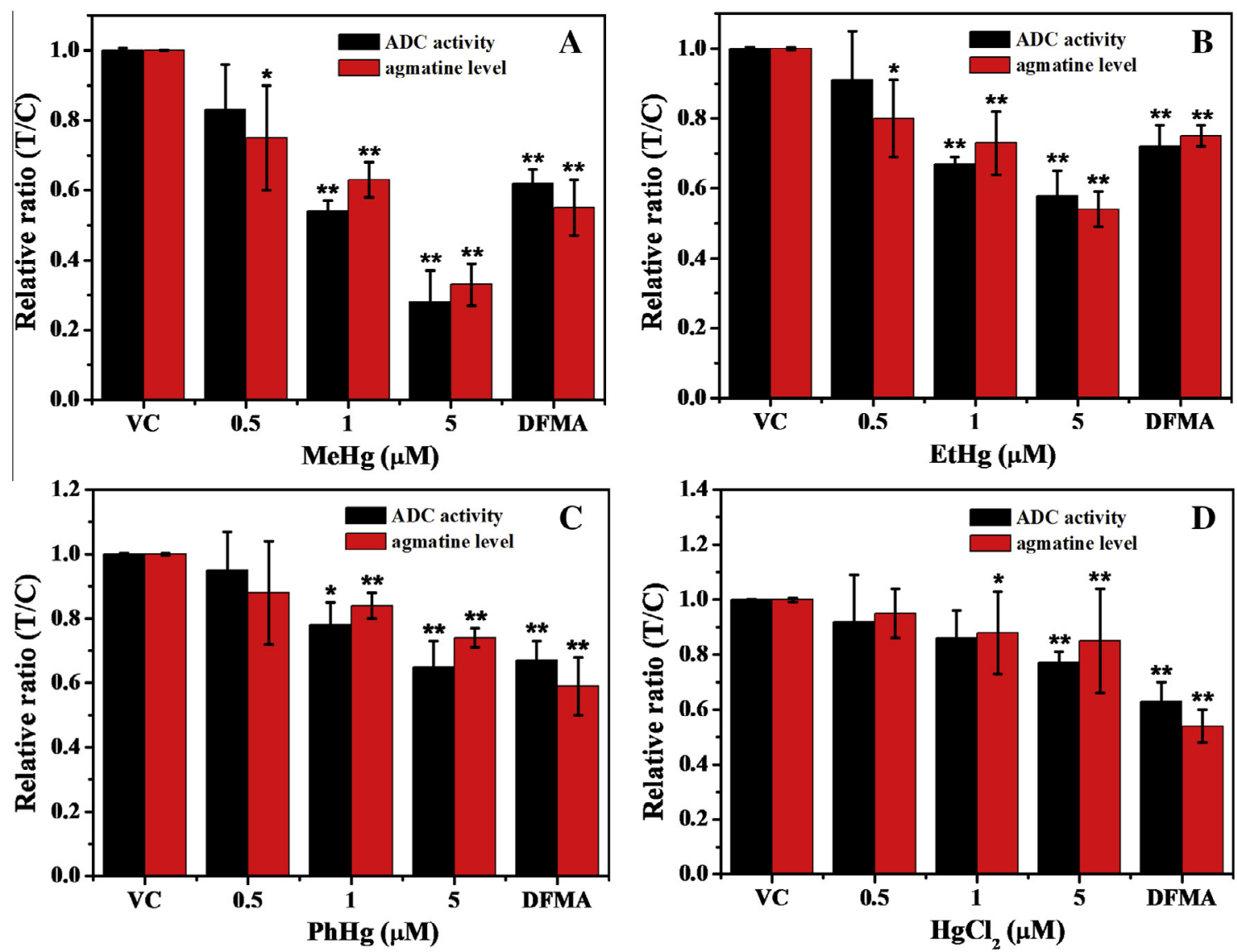

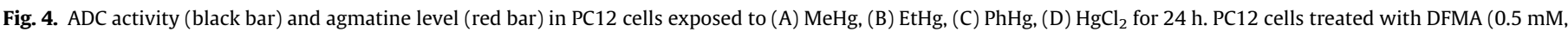

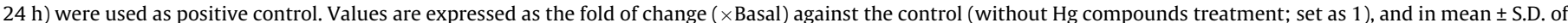

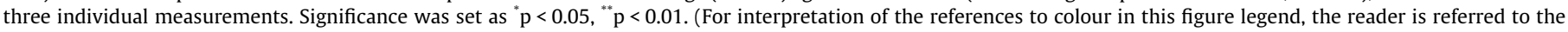
web version of this article.) 
$1.2 \mu \mathrm{g} \mathrm{mL}^{-1}$ and $20 \mu \mathrm{M}$ (Fig. 2A, B). The limit of detection for ADC is $0.02 \mu \mathrm{g} \mathrm{mL}^{-1}$ (signal-to-noise ratio of 3), which is much lower than the values in the CB7/Dapoxyl and CX4/DBO systems [41].

Having established the ADC activity assay, inhibitions of four $\mathrm{Hg}$ compounds on ADC activity were examined. The assay was first verified by reacting with difluoromethyl arginine (DFMA), a specific ADC inhibitor. The fluorescence intensity increased progressively with the concentration of DFMA until it reached a plateau (Fig. 2C). The $\mathrm{IC}_{50}$ value was $0.49 \mathrm{mM}$. $K_{i}$ was calculated to be $0.47 \mathrm{mM}$ which is close to that reported in the literature $\left(K_{i}=0.80\right.$ $\mathrm{mM})$ [42].

In the following experiments, four $\mathrm{Hg}$ compounds including inorganic $\mathrm{HgCl}_{2}$ and organic $\mathrm{MeHg}, \mathrm{EtHg}$ and $\mathrm{PhHg}$ were tested for their inhibitory effects on ADC. Addition of a $\mathrm{Hg}$ compound into a CB7/AO solution did not induce any fluorescence change, suggesting that the chemical does not interfere with the signaling system. As shown in Fig. 2D, all the $\mathrm{Hg}$ compounds inhibited ADC activity in a concentration-dependent manner. But their inhibition potency differed significantly, as demonstrated by their $\mathrm{IC}_{50}$ values summarized in Table 1 . For the four $\mathrm{Hg}$ compounds, the inhibitory effects of organic $\mathrm{Hg}$ were stronger than that of inorganic $\mathrm{Hg}$. The inhibitory effects followed the order of $\mathrm{MeHg}>\mathrm{EtHg}>\mathrm{PhHg}>$
$\mathrm{HgCl}_{2}$. Among them, MeHg showed the strongest inhibitory potency on ADC with a $\mathrm{IC}_{50}$ of $7.96 \mathrm{nM}$, which is much stronger than DFMA.

\subsection{Inhibition of ADC activity by Hg compounds in PC12 cells}

PC12 cell was selected to further verify the effects of Hg compounds on ADC activity in cells due to high expression of ADC. It was necessary for us to first examine the effects of $\mathrm{Hg}$ compounds on cell viability so as to obtain the dose-effect curves. WST-1 assay was employed to detect the cell viability of PC12 cells after $24 \mathrm{~h}$ incubation with a series of concentrations of $\mathrm{MeHg}, \mathrm{EtHg}, \mathrm{HgCl}_{2}$ $(0-50 \mu \mathrm{M})$ and $\mathrm{PhHg}(30 \mu \mathrm{M})$. Cell viability significantly decreased at $10 \mu \mathrm{M}, 15 \mu \mathrm{M}$ and $20 \mu \mathrm{M}$ when exposed to $\mathrm{MeHg}$ (or EtHg), $\mathrm{PhHg}$ and $\mathrm{HgCl}_{2}$ respectively (Fig. 3). The order of cytotoxicity is $\mathrm{MeHg} \approx \mathrm{EtHg}>\mathrm{PhHg}>\mathrm{HgCl}_{2}$. Then, $\mathrm{PC1} 2$ cells were exposed to one of the $\mathrm{Hg}$ compounds at non-cytotoxic concentrations for $24 \mathrm{~h}$. Thereafter, an appropriate amount of cell lysate containing $30 \mu \mathrm{g}$ protein was mixed with arginine at $37^{\circ} \mathrm{C}$ for $1.5 \mathrm{~h}$, ADC activity was determined by measuring the agmatine amount produced enzymatically. As shown in Fig. 4, four $\mathrm{Hg}$ compounds were all found to inhibit the ADC activity in a concentration-dependent
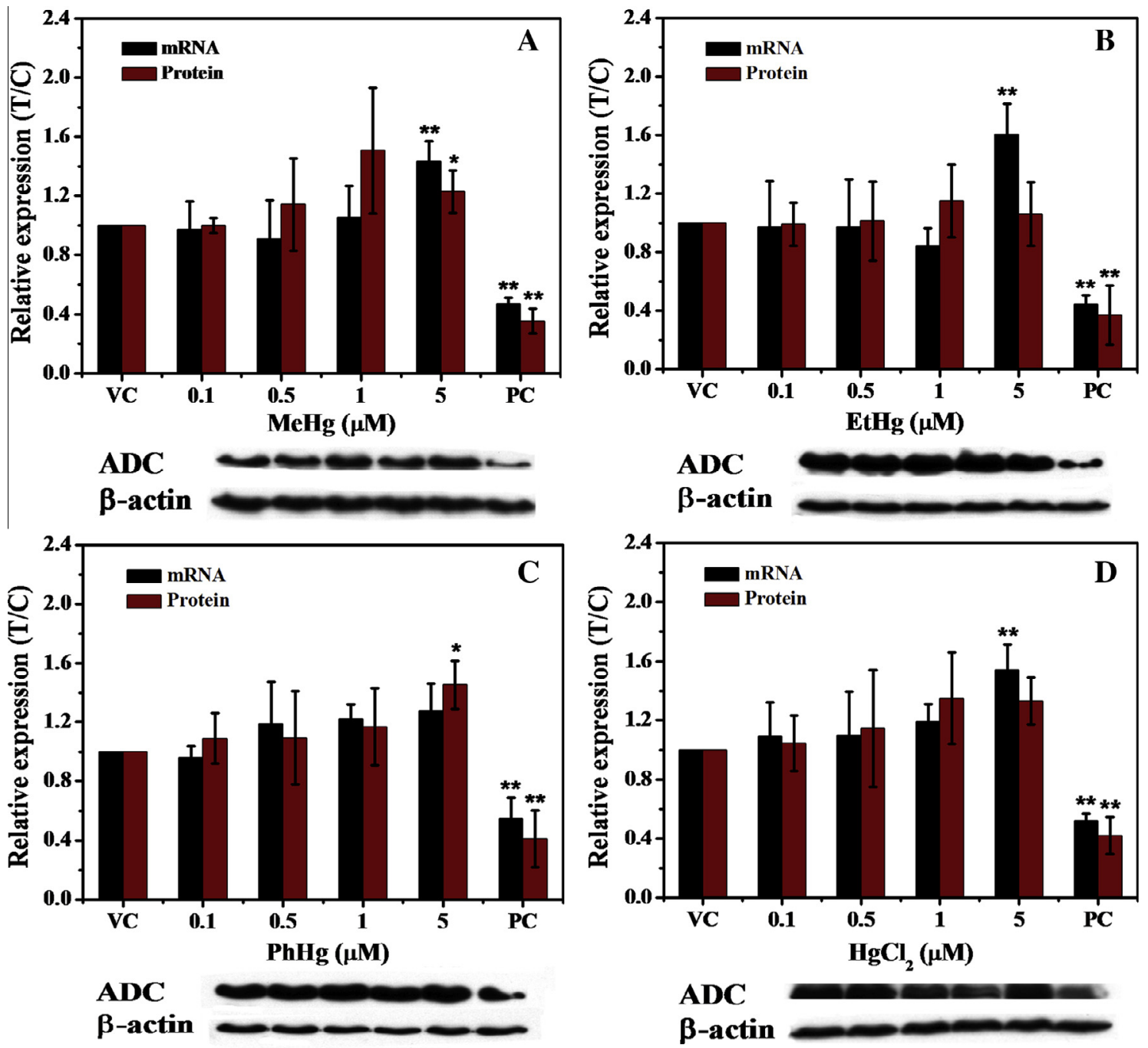

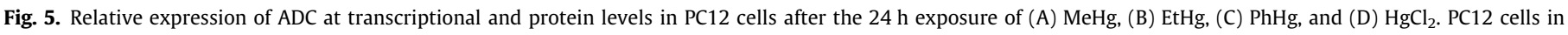

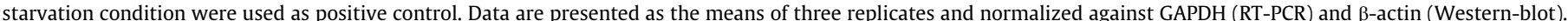

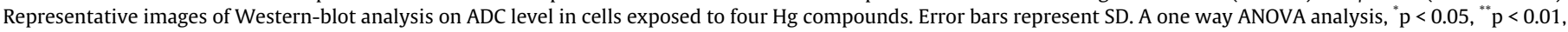
compared with the control group $(\mathrm{T} / \mathrm{C})$. 
manner. Among them, the significant decrease of ADC activity was observed at $5 \mu \mathrm{M}$ MeHg exposure and the relative ADC activity was a $72 \%$ decrease (Fig. 4A). By contrast, upon other Hg compounds exposure, the relative ADC activity at the same concentration was $42 \%, 35 \%$ and $23 \%$ decrease $\left({ }^{* *} \mathrm{p}<0.01\right.$ ), respectively (Fig. $4 \mathrm{~B}-$ D). The inhibition strength follows the order: $\mathrm{MeHg}>\mathrm{EtHg}>$ $\mathrm{PhHg}>\mathrm{HgCl}_{2}$. This demonstrates that the remarkable inhibitory effects of $\mathrm{Hg}$ compounds on ADC activity were also observed in living cells, which further verify the results obtained from the fluorescence assay.

In practice, the enzymatic activity measurement of a protein varies with both total amount and specific activity of the protein. Therefore, we need determine the gene expressions as well as the ADC protein levels of cells after $\mathrm{Hg}$ compounds exposure. The results of RT-PCR showed that the gene expression of ADC was not restrained when exposed to the four $\mathrm{Hg}$ compounds respectively (Fig. 5A-D). The ADC protein level in exposed cells was quantified using western-blot assay. $\mathrm{Hg}$ compounds exposure did not result in the decrease of ADC level in cells. Instead, $5 \mu \mathrm{M} \mathrm{MeHg}$, EtHg, $\mathrm{PhHg}$ and $\mathrm{HgCl}_{2}$ increased the protein expression by 1.23-, $1.06-, 1.45$ and 1.33 -fold, respectively (Fig. 5A-D). The results indicate that ADC inhibition in PC12 cells by the four $\mathrm{Hg}$ compounds was indeed due to the loss of enzyme activity, not protein level.

\subsection{Agmatine level in exposed cells}

As aforementioned, the biosynthesis of agmatine in cells is regulated by ADC. The inhibition of ADC activity by $\mathrm{Hg}$ compounds should lead to a decrease of agmatine level. Therefore, we further investigated the effects of $\mathrm{Hg}$ compounds on agmatine levels in cells. After exposure to one of the four $\mathrm{Hg}$ compounds, PC12 cells were lysed and derivatized with OPA, the agmatine amount was then determined by HPLC. Compared with control cells, Hg compounds treated cells had a dose-dependent reduction in the agmatine levels (Fig. 5A-D). At the concentration of $5 \mu \mathrm{M}, \mathrm{MeHg}, \mathrm{EtHg}$, $\mathrm{PhHg}$ and $\mathrm{HgCl}_{2}$ lowered the agmatine levels by $67 \%, 46 \%, 28 \%$, and $15 \%$, respectively. The changes of agmatine levels were apparently manifested in cells exposed to $\mathrm{Hg}$ compounds, further confirming the inhibition of ADC activity.

\subsection{Detection of $\mathrm{MeHg}$ in immunoprecipitated $A D C$ from exposed cells}

Based on the fluorescence assay results, we postulated that the inhibition of ADC activity and decrease of agmatine level in PC12 cells upon $\mathrm{MeHg}$ exposure was ascribed to the direct binding of $\mathrm{MeHg}$ with ADC. To prove this point, PC12 cells were exposed to $5 \mu \mathrm{M} \mathrm{MeHg}$ for $24 \mathrm{~h}$, and then rinsed extensively to remove the

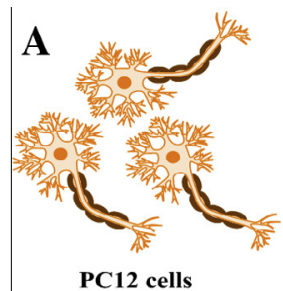

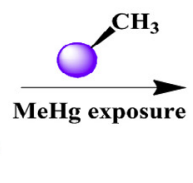

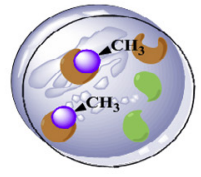

Dynabeads coated with anti-ADC antibody

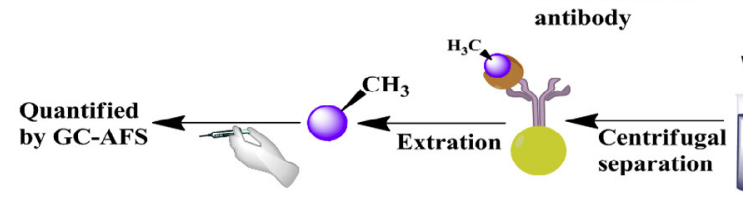

C

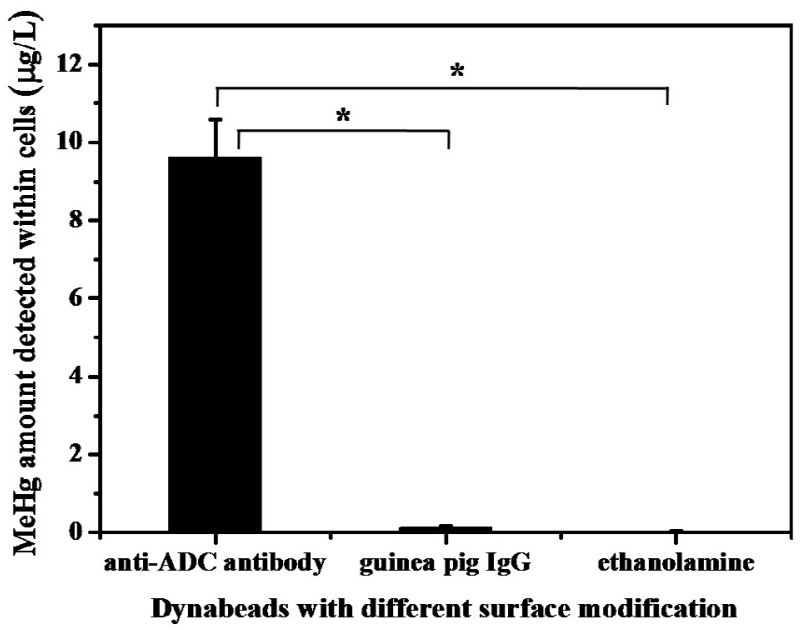

B
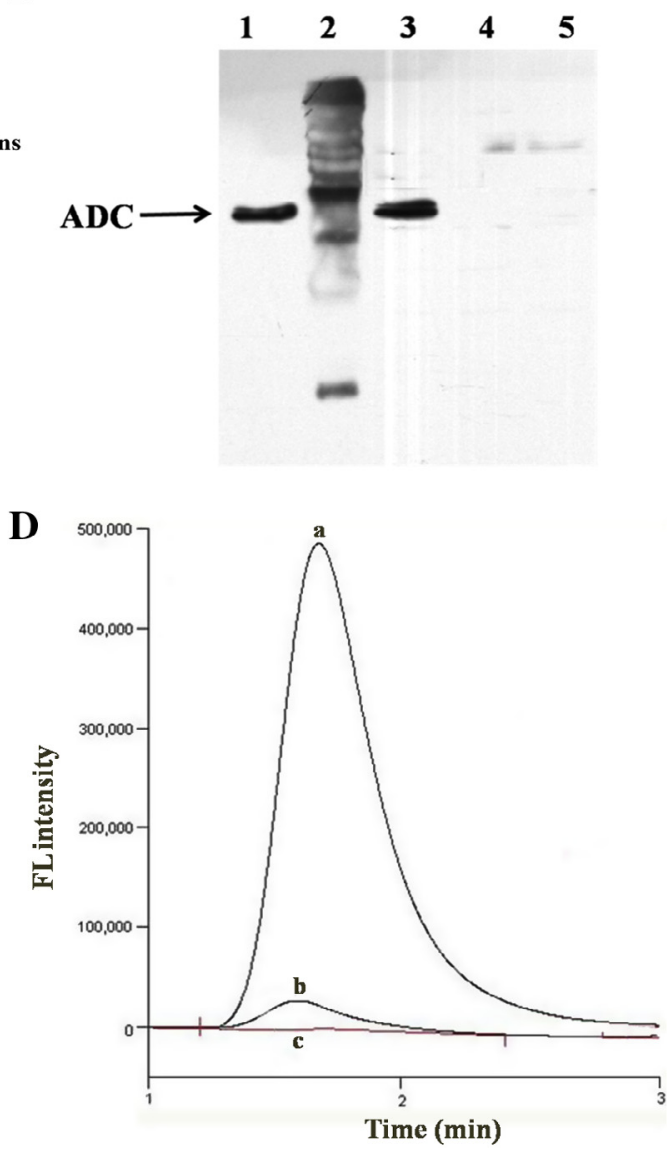

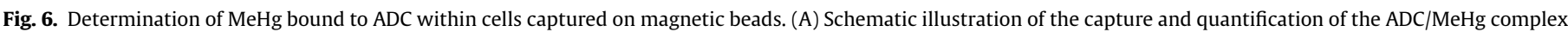

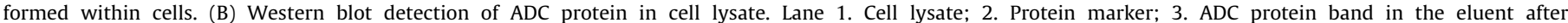

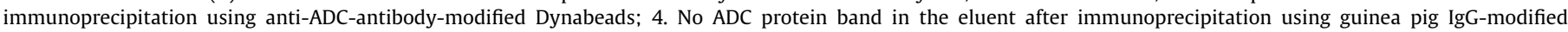

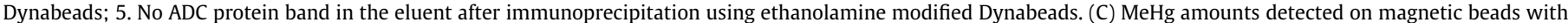

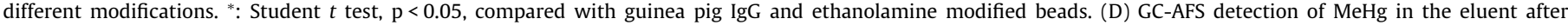

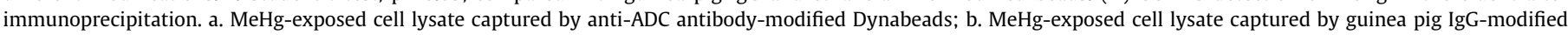
Dynabeads; c. MeHg-exposed cell lysate captured by ethanolamine-modified Dynabeads. 
compound adsorbed on the surface of the cells. Dynabeads coated with anti-ADC antibody were added into the lysate of the exposed cells to capture the protein (Fig. 6A, B). The bead sample was treated and then analyzed for ADC and $\mathrm{MeHg}$ content. The amount of ADC captured on the beads was measured to be $0.035 \mathrm{nmol}$ by BCA protein quantification, And the $\mathrm{MeHg}$ amount detected in the anti-ADC antibody coated bead sample by GC-AFS is $9.52 \mu \mathrm{g} / \mathrm{L}$ (i.e. $0.038 \mathrm{nmol}$ ), which is much higher than those detected in the guinea pig IgG coated beads $(0.12 \mu \mathrm{g} / \mathrm{L})$ and ethanolamine-blocked beads $(0.03 \mu \mathrm{g} / \mathrm{L})$ (Fig. 6C, D). Since both $\mathrm{MeHg}$ and ADC were detected on the beads, it can be deduced that $\mathrm{MeHg}$ bound directly to ADC in the exposed PC12 cells. The binding ratio of $\mathrm{MeHg}$ to $\mathrm{ADC}$ can be estimated to be 1.08 .

\subsection{The inhibition mechanism of $\mathrm{Hg}$ compounds on ADC activity}

To better understand the inhibitory effects of $\mathrm{Hg}$ compounds on ADC activity, the effects of $\mathrm{Hg}$ compounds on the complex formed by ADC, cofactor pyridoxal 5'-phosphate (PLP) and substrate arginine were investigated by molecular dynamics simulation. The decarboxylation reaction catalyzed by ADC is dependent on the cofactor PLP. PLP is a common cofactor to enzymes primarily involved in the metabolism of amino acids. These PLP-dependent enzymes are capable of catalyzing a broad range of chemical reactions such as transamination, racemization, and elimination and replacement reactions in addition to decarboxylation. The PLP cofactor is capable of slowly catalyzing many of these reactions
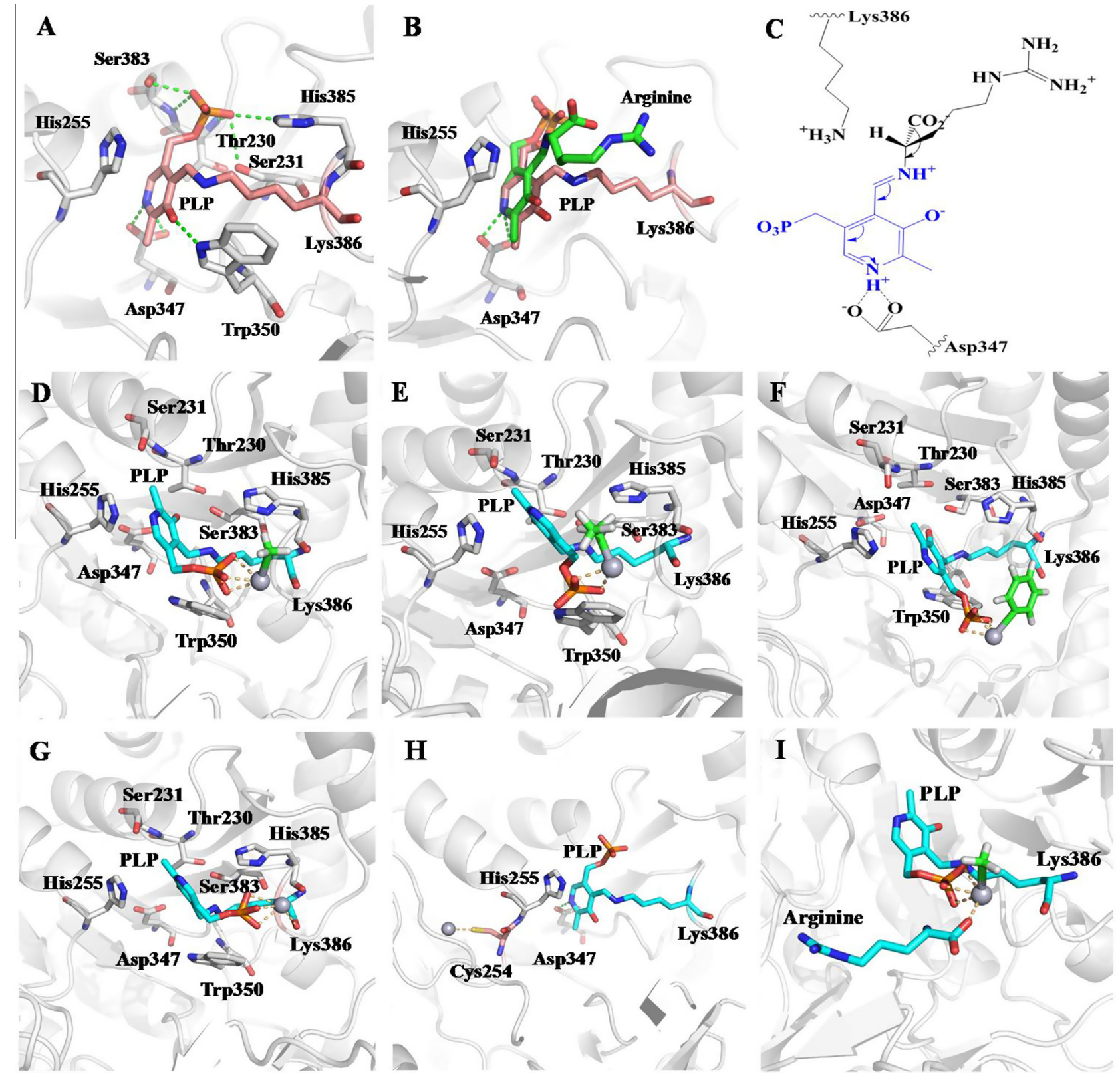

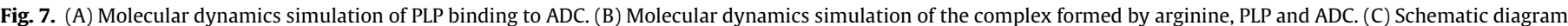

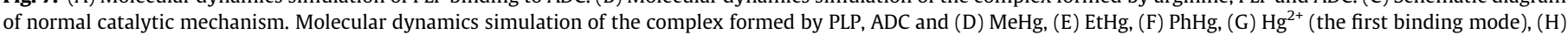

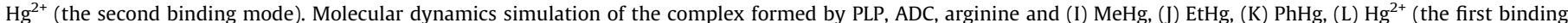

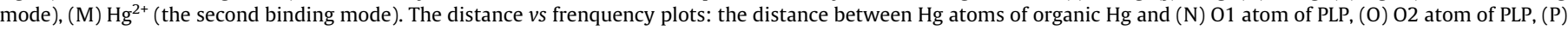
$\mathrm{O} 3$ atom of PLP. Angle $v s$ frenquency plots: $(\mathrm{Q})$ the angle $\alpha$ among $\mathrm{O}$ atom, $\mathrm{Hg}$ atom and P atom, (R) The angle $\beta$ among $\mathrm{O}$ atom, $\mathrm{Hg}$ atom and $\mathrm{C} \alpha$ of organic $\mathrm{Hg}$. 

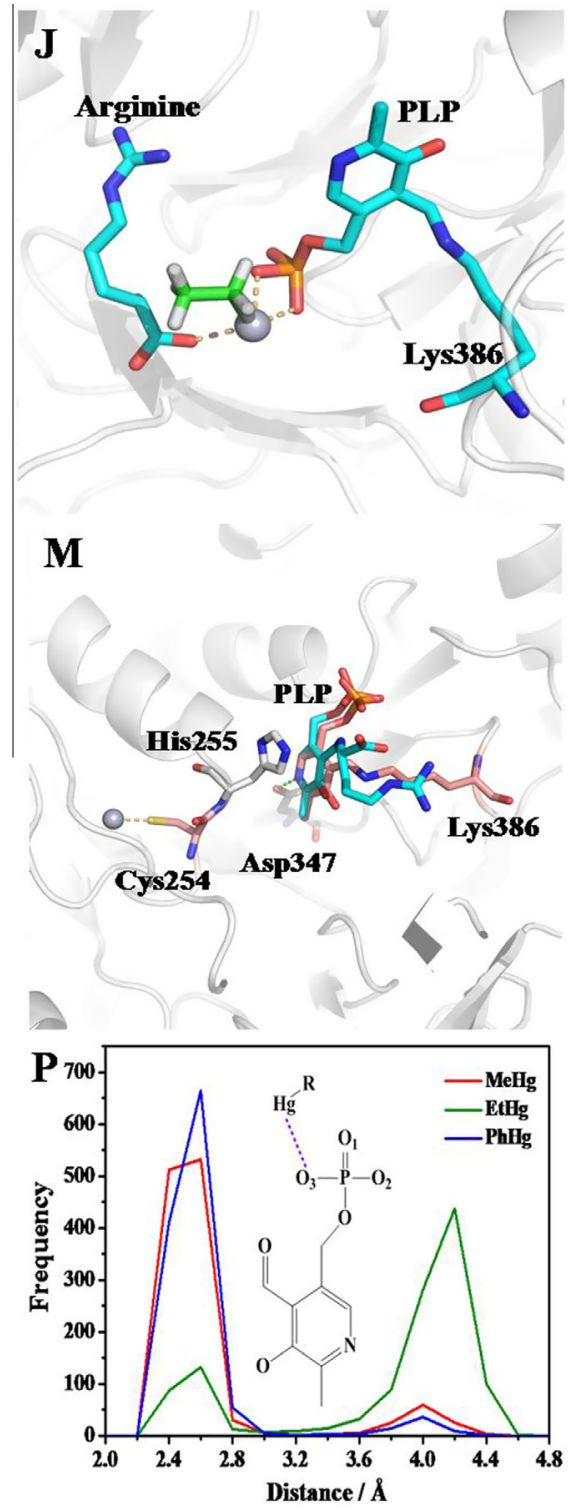
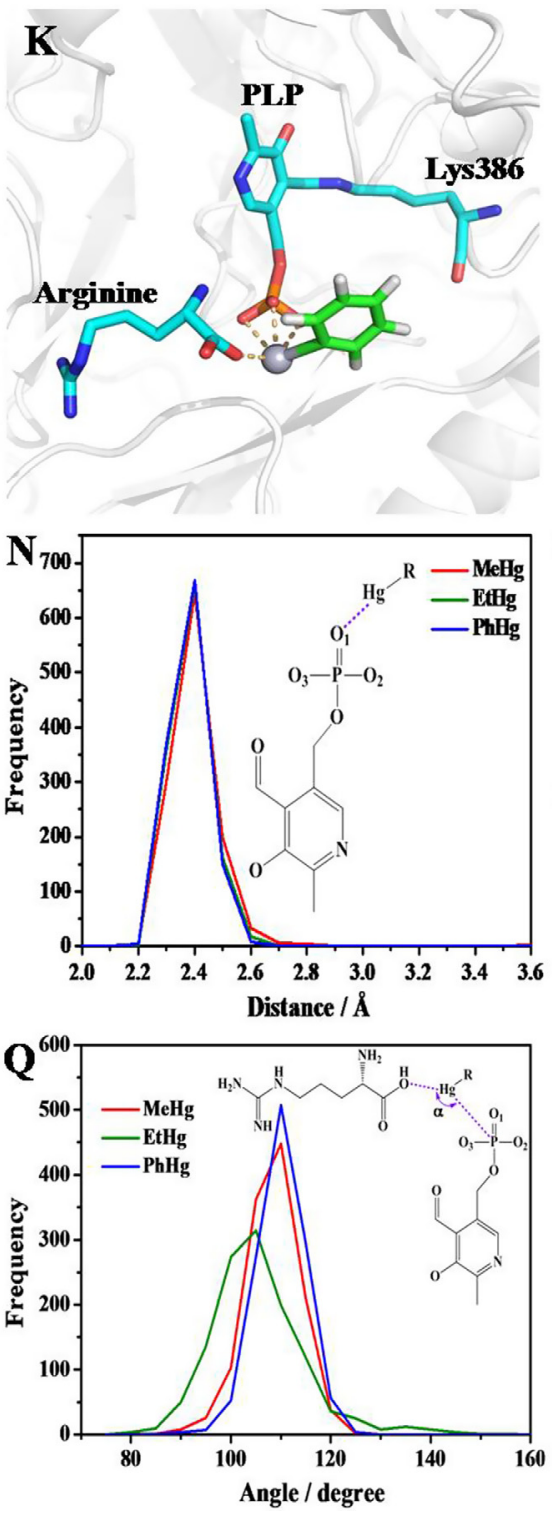

Fig. 7 (continued)
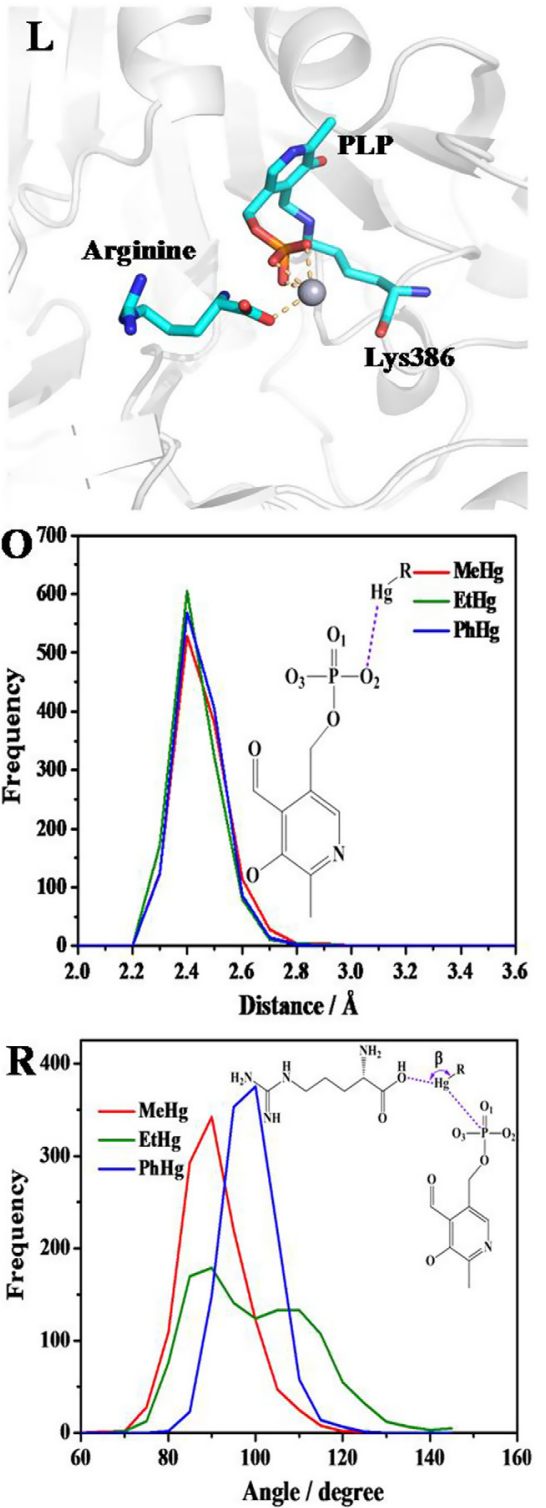

in the absence of enzyme. The function of the protein is thus to provide substrate and reaction specificity and to enhance the catalytic properties of the PLP. Results show that some interactions exist between the ADC and PLP cofactor (Fig. 7A). There are five hydrogen bonds between the phosphate group of the PLP and residues His385, Ser383, Thr230, Ser231 of ADC monomer. The N atom of the pyridine ring forms a salt bridge with Asp347, and the indole of Trp350 forms a hydrogen bond to the pyridine ring 3-oxygen. A lysine residue (Lys386) forms a covalent Schiff base linkage with the $C$ atom of the PLP pyridine ring. Moreover, in the absence of $\mathrm{Hg}$ compounds, the substrate arginine can attack the $\mathrm{N}$ atom of PLP in catalytic domain and form a correct catalytic conformation with PLP and ADC to complete catalysis (Fig. 7B). That is, in the resting state of the enzyme, Lys386 forms an internal aldimine with the PLP cofactor. Lys386 residue will be displaced in a transimination reaction by the substrate L-arginine, forming an arginine aldimine with the PLP cofactor through a covalent bond between the $\mathrm{C} 4^{\prime}$ position of the pyridine ring and the amino group of L-arginine. The Asp347 residue provides a stabilizing negative charge to the protonated pyridine nitrogen, which enhances the electron-withdrawing properties of the cofactor (Fig. 7C). Our sim- ulation results are in good agreement with those published in the literature [43]. Then, in the presence of $\mathrm{Hg}$ compounds, the interactions between the ADC and PLP were disrupted. $\mathrm{Hg}$ atom will form strong interactions with three $\mathrm{O}$ atoms in PO3 of PLP. Except $\mathrm{EtHg}$, there were three coordination bonds between $\mathrm{Hg}$ atoms in other three $\mathrm{Hg}$ compounds and $\mathrm{O}$ atoms in PO3 of PLP (Fig. 7D$\mathrm{G})$. $\mathrm{Hg}$ atoms in $\mathrm{MeHg}$ and $\mathrm{PhHg}$ all formed stable coordination bonds with atoms $\mathrm{O} 1, \mathrm{O} 2$ and $\mathrm{O} 3$ of $\mathrm{PO} 3$ and the distances of interactions have been centered in the range from 2.2 to $2.8 \AA$. By contrast, $\mathrm{Hg}$ atom in EtHg only coordinated with atoms $\mathrm{O} 1$ and $\mathrm{O} 2$ of $\mathrm{PO} 3$ in the same distances as MeHg and PhHg (Fig. 7N-P). Also, for inorganic $\mathrm{Hg}$, there was another binding site and $\mathrm{Hg}^{2+}$ could form the coordination bond with - $\mathrm{SH}$ group of Cys254 in ADC (Fig. $7 \mathrm{H}$ ). The binding energies of $\mathrm{Hg}$ compounds with cofactor PLP and ADC were calculated and listed in Table 1. Furthermore, in the presence of substrate L-arginine, $\mathrm{Hg}$ atoms in $\mathrm{Hg}$ compounds formed coordination bonds not only with $\mathrm{O}$ atoms in PO3 of PLP, but also with $\mathrm{O}$ atom in substrate (Fig. 7I-L). These interactions prevented substrate arginine from forming the correct catalytic conformation with PLP and ADC. For inorganic Hg, the binding of $\mathrm{Hg}^{2+}$ with Cys254 could not affect the catalytic reaction of enzyme 
(Fig. 7M). In addition, the angle $\alpha$ of interaction among $\mathrm{O}$ atom of substrate arginine, $\mathrm{Hg}$ atom and $\mathrm{P}$ atom of PLP was distributed at $109^{\circ}$ for $\mathrm{MeHg}$ and $\mathrm{PhHg}$, and in a disperse state for $\mathrm{EtHg}$ (Fig. 7Q). Moreover, the angle $\beta$ of interaction among $\mathrm{O}$ atom of substrate arginine, $\mathrm{Hg}$ atom and $\mathrm{C} \alpha$ atom of organic $\mathrm{Hg}$ was almost distributed at $90^{\circ}$ for $\mathrm{MeHg}$, at about $100^{\circ}$ for $\mathrm{PhHg}$, and in a disperse state for EtHg (Fig. 7R).

\section{Discussion}

The most notable toxicity of $\mathrm{Hg}$ compounds on human and experimental animals is neurotoxicity. ADC is responsible for the biosynthesis of agmatine and ADC's biological importance is closely linked to the function of the agmatine. Agmatine is a neuroprotective molecule and reduces excitotoxic cell death induced by glutamate or NMDA. In the brain, agmatine is synthesized from arginine by $\mathrm{ADC}$ and degraded by agmatinase. Thus, increasing endogenous agmatine either by increasing ADC activity or by blocking agmatinase activity has become a novel mechanism to protect against conditions arising from higher NMDA receptor activation. In our work, a set of experiments were carried out in an attempt to establish ADC as a potential target of $\mathrm{Hg}$ compounds in neuron cells and to provide a novel molecular mechanism for neurotoxicity action of $\mathrm{Hg}$ compounds.

In the in vitro ADC enzyme activity assay, all the four $\mathrm{Hg}$ compounds inhibited ADC activity. Their inhibition potencies were strongly dependent on the $\mathrm{Hg}$ species, with $\mathrm{MeHg}$ being the strongest and $\mathrm{HgCl}_{2}$ the weakest. Molecular dynamics simulation provided rationales for the differences in their structure-dependent inhibition potency. For the organic $\mathrm{Hg}$ compounds, the calculated binding energies followed the order: $\mathrm{MeHg}>\mathrm{EtHg}>\mathrm{PhHg}$ (Table 1). This trend correlates very well with the experimentally measured inhibition potency $\left(\mathrm{IC}_{50}\right)$ of $\mathrm{Hg}$ compounds, and therefore supports the validity of the molecular dynamics simulation approach.

In the system including $\mathrm{Hg}$ compounds, ADC and PLP, all the $\mathrm{Hg}$ compounds were located in the active pocket of ADC, and formed strong interactions with PLP. The interactions caused PLP to twist in ADC catalytic domain. In the presence of substrate arginine, $\mathrm{Hg}$ atoms in three organic $\mathrm{Hg}$ compounds also formed coordination bonds with $\mathrm{O}$ atom of arginine, which destroyed the interaction between arginine and PLP and hindered the occurrence of normal catalytic reaction. Also, for $\mathrm{MeHg}$ and $\mathrm{PhHg}$, the substituent methyl and phenyl located in a upright posture when they bound with arginine and PLP. While for EtHg, the ethyl located in a bent posture when it bound with arginine and PLP. The larger steric hindrance keeps arginine away from PLP and blockades the interaction between $\mathrm{Hg}$ atom in $\mathrm{EtHg}$ and atom $\mathrm{O} 3$ of $\mathrm{PO}$. Furthermore, for $\mathrm{MeHg}$ and $\mathrm{EtHg}$, the angle distributions among $\mathrm{O}$ atom of arginine, $\mathrm{Hg}$ atom and PLP were stable. While for $\mathrm{EtHg}$, the angle distribution was disperse. The possible reason was that the steric hindrance of $\mathrm{MeHg}$ was the smallest, and the phenyl group of $\mathrm{PhHg}$ could form the Pi-Pi interaction with other amino acid residues of ADC. Thus, they exhibited the more stable angle distributions in comparison with EtHg. For inorganic Hg, there are two kinds of binding modes among $\mathrm{Hg}^{2+}$, PLP and ADC. Although the second mode binding by the $\mathrm{Hg}^{2+}$ and $-\mathrm{SH}$ group of Cys254 could not affect the enzyme catalysis, it could cause the decrease of $\mathrm{Hg}^{2+}$ amounts which bound with PLP through the first mode. This may explain why $\mathrm{Hg}^{2+}$ is less potent inhibitor than organic Hg compounds.

The molecular dynamics simulation results may also be used to rationalize the structure-dependent inhibition potency observed in the cells based on ADC activity assays. Moreover, the gene and protein expressions of ADC were not suppressed by $\mathrm{Hg}$ compounds, but ADC enzymatic activities were all reduced after $\mathrm{Hg}$ compounds exposure and agmatine levels in PC12 cells decreased subse- quently. This indicated that the decrease of ADC activity was indeed caused by the inhibition of $\mathrm{Hg}$ compounds, rather than by the changes of ADC expression level. Further, the complex formed by direct binding of MeHg to the ADC was identified using the immunoprecipitation method. Dynabeads coated with anti-ADC antibody could selectively capture ADC in the cell lysate. During the process, any $\mathrm{MeHg}$ bound to the protein would also be captured by the beads. A significant amount of $\mathrm{MeHg}$ was detected by GC-AFS in the bead sample. Instead, very few of MeHg was detected on the uncoated beads, and small amounts of $\mathrm{MeHg}$ was detected on the IgG-coated beads, probably due to some non-specific bindings. These results provide unequivocal evidence for the direct binding of $\mathrm{MeHg}$ to ADC in PC12 cells. The agreement in the 1:1 binding mode between the simulated complex and the immunoprecipitation experiment provides further support.

Agmatine, a cationic polyamine synthesized after decarboxylation of L-arginine by the enzyme ADC, is an endogenous neuromodulator that emerges as a potential agent to manage diverse CNS disorders. Therefore, inhibition of ADC activity should lead to a decrease in agmatine. We evaluated the effects of ADC inhibition by $\mathrm{Hg}$ compounds in PC12 cells. As expected, all the four Hg compounds caused a significant decrease of agmatine levels in PC12 cells. Some evidences have extended our understanding of how agmatine may be effective in managing CNS disorders. Although a specific ('own') agmatine postsynaptic receptor has not been identified, agmatine binds with high affinity to all subclasses of a2-adrenoceptors and imidazoline binding sites. Moreover, it interacts with nicotinic cholinergic receptors, serotonin 5-HT3 receptors and blocks ligand-gated cation channels, particularly the NMDA glutamate receptor. At the intracellular level, it modulates the productions of polyamines (involved in pro-mitotic processes) and inhibits NOS in rodents. Furthermore, agmatine has anti-inflammatory properties and exerts protection against oxidative stress induced by increased mitochondrial volume, collapse of mitochondrial membrane potential and apoptosis by scavenging free radicals. Moreover, agmatine induces its cellular and molecular effects, at least partially, by activating neurotrophic and neuroprotective pathways. It remains to be seen whether ADC inhibition would have any impacts on the CNS disorders of experimental animals.

In summary, using a combined experimental approach including fluorescence-based enzyme activity assay, cell-based assays and molecular dynamics simulation, we have established ADC as a novel cellular target of $\mathrm{Hg}$ compounds in PC12 cells. Upon cell exposure, $\mathrm{Hg}$ compounds enter the cell, inhibit ADC decarboxylation reaction for arginine, and thereby decrease the level of agmatine, a neuroprotective and neurorescue agent in vivo. Molecular dynamics simulation revealed that the species of $\mathrm{Hg}$ compounds and their coordination bonding with $\mathrm{O}$ atoms of PLP cofactor are the important structural characteristics for them to inhibit ADC activity. Further studies are needed to investigate the effects of ADC inhibition on CNS disorders of experimental animals and its possible link to the toxic effects observed on human neurological and neurodegenerative diseases including epilepsies, depression, traumatic brain injury, Parkinson's disease (PD) and Alzheimer's disease (AD).

\section{Conflict of interest}

None of the authors have any conflict of interest to declare.

\section{Acknowledgments}

This work was supported by the Chinese Academy of Sciences (XDB14040100), National Basic Research Program of China 
(2015CB932003) and National Natural Science Foundation of China (No. 21321004, 21375143, 21577163, 21377142, 91543203, 21477146, 21407168). We thank Prof. Jianbo Shi and PhD Chengbin Liu for their kind help.

\section{References}

[1] C.T. Driscoll, R.P. Mason, H.M. Chan, D.J. Jacob, N. Pirrone, Mercury as a global pollutant: sources, pathways, and effects, Environ. Sci. Technol. 47 (2013) 4967-4983.

[2] N. Pirrone, S. Cinnirella, X. Feng, R.B. Finkelman, H.R. Friedli, J. Leaner, R. Mason, A.B. Mukherjee, G.B. Stracher, D.G. Streets, K. Telmer, Global mercury emissions to the atmosphere from anthropogenic and natural sources, Atmos. Chem. Phys. 10 (2010) 5951-5964.

[3] T.W. Clarkson, L. Magos, The toxicology of mercury and its chemical compounds, Crit. Rev. Toxicol. 36 (2006) 609-662.

[4] C.C. Bridges, R.K. Zalups, Transport of inorganic mercury and methylmercury in target tissues and organs, J. Toxicol. Environ. Health B 13 (2010) 385-410.

[5] J.S. Woods, Mercury and the central nervous system, Environ. Health Perspect. 110 (2002). A177-A177.

[6] H. Gibb, K.G. O'Leary, Mercury exposure and health impacts among individuals in the artisanal and small-scale gold mining community: a comprehensive review, Environ. Health Perspect. 122 (2014) 667-672.

[7] B.F. Azevedo, L.B. Furieri, F.M. Pecanha, G.A. Wiggers, P.F. Vassallo, M.R. Simoes, J. Fiorim, Toxic effects of mercury on the cardiovascular and central nervous systems, J. Biomed. Biotechnol. (2012), http://dx.doi.org/10.1155/2012/ 949048.

[8] J. Vas, M. Monestier, Immunology of mercury, Ann. N. Y. Acad. Sci. 1143 (2008) 240-267.

[9] P.B. Tchounwou, W.K. Ayensu, N. Ninashvili, D. Sutton, Environmental exposure to mercury and its toxicopathologic implications for public health, Environ. Toxicol. 18 (2003) 149-175.

[10] S.A. Counter, L.H. Buchanan, Mercury exposure in children: a review, Toxicol. Appl. Pharmacol. 198 (2004) 209-230.

[11] M. Aschner, N. Onishchenko, S. Ceccatelli, Toxicology of alkylmercury compounds, Met. Ions Life Sci. 7 (2010) 403-434.

[12] A. Osinka, K. Pasternak, Mercury in medicine and health service, J. Elementol. 19 (2014) 289-297.

[13] F.M. Yilmaz, H. Yilmaz, E. Tutkun, S. Uysal, K.B. Carman, C. Dilber, M. Ercan, Serum biochemical markers of central nerve system damage in children with acute elemental mercury intoxication, Clin. Toxicol. 52 (2014) 32-38.

[14] M. Aschner, T. Syversen, Methylmercury - recent advances in the understanding of its neurotoxicity, Ther. Drug Monit. 27 (2005) 278-283.

[15] S.J.B. Fretham, S. Caito, E.J. Martinez-Finley, M. Aschner, Mechanisms and modifiers of methylmercury-induced neurotoxicity, Toxicol. Res. 1 (2012) 32 38.

[16] S. Diez, Human health effects of methylmercury exposure, Rev. Environ. Contam. Toxicol. 198 (2009) 111-132.

[17] Z.B. Yin, H.Y. Jiang, T. Syversen, J.B.T. Rocha, M. Farina, M. Aschner, The methylmercury-L-cysteine conjugate is a substrate for the L-type large neutral amino acid transporter, J. Neurochem. 107 (2008) 1083-1090.

[18] J. Stringari, A.K.C. Nunes, J.L. Franco, D. Bohrer, S.C. Garcia, A.L. Dafre, D. Milatovic, D.O. Souza, J.B.T. Rocha, M. Aschner, Prenatal methylmercury exposure hampers glutathione antioxidant system ontogenesis and causes long-lasting oxidative stress in the mouse brain, Toxicol. Appl. Pharmacol. 227 (2008) 147-154.

[19] J.L. Franco, T. Posser, P.R. Dunkley, P.W. Dickson, J.J. Mattos, R. Martins, A.C.D. Bainy, M.R. Marques, A.L. Dafre, M. Farina, Methylmercury neurotoxicity is associated with inhibition of the antioxidant enzyme glutathione peroxidase Free Radical Biol. Med. 47 (2009) 449-457.

[20] M. Aschner, T. Syversen, D.O. Souza, J.B.T. Rocha, M. Farina, Involvement of glutamate and reactive oxygen species in methylmercury neurotoxicity, Braz. J. Med. Biol. Res. 40 (2007) 285-291.

[21] D.E. Featherstone, Intercellular glutamate signaling in the nervous system and beyond, ACS Chem. Neurosci. 1 (2010) 4-12.
22] C.F. Huang, C.J. Hsu, S.H. Liu, S.Y. Lin-Shiau, Neurotoxicological mechanism of methylmercury induced by low-dose and long-term exposure in mice: oxidative stress and down-regulated $\mathrm{Na}^{+} / \mathrm{K}^{+}$-ATPase involved, Toxicol. Lett. 176 (2008) 188-197.

[23] Y. Ohgi, T. Futamura, K. Hashimoto, Glutamate signaling in synaptogenesis and NMDA receptors as potential therapeutic targets for psychiatric disorders, Curr. Mol. Med. 15 (2015) 206-221.

[24] N.B. Pivovarova, S.B. Andrews, Calcium-dependent mitochondrial function and dysfunction in neurons, FEBS J. 277 (2010) 3622-3636.

[25] T.L. Limke, S.R. Heidemann, W.D. Atchison, Disruption of intraneuronal divalent cation regulation by methylmercury: are specific targets involved in altered neuronal development and cytotoxicity in methylmercury poisoning? Neurotoxicology 25 (2004) 741-760.

[26] S. Regunathan, D.J. Reis, Characterization of arginine decarboxylase in rat brain and liver: distinction from ornithine decarboxylase, J. Neurochem. 74 (2000) 2201-2208.

[27] W. Raasch, S. Regunathan, G. Li, D.J. Reis, Agmatine, the bacterial amine, is widely distributed in mammalian-tissues, Life Sci. 56 (1995) 2319-2330.

[28] O. Yesilyurt, I.T. Uzbay, Agmatine potentiates the analgesic effect of morphine by an a2-adrenoceptor-mediated mechanism in mice, Neuropsychopharmacology 25 (2001) 98-103.

[29] D.J. Reis, S. Regunathan, Agmatine: an endogenous ligand at imidazoline receptors is a novel neurotransmitter, Ann. N. Y. Acad. Sci. 881 (1999) 65-80.

[30] X.C. Yang, D.J. Reis, Agmatine selectively blocks the N-methyl-D-aspartate subclass of glutamate receptor channels in rat hippocampal neurons, J. Pharmacol. Exp. Ther. 288 (1999) 544-549.

[31] T.I. Uzbay, The pharmacological importance of agmatine in the brain, Neurosci. Biobehav. Rev. 36 (2012) 502-519.

[32] G. Olmos, N. DeGregorio-Rocasolano, M.P. Regalado, T. Gasull, M.A. Boronat, R Trullas, A. Villarroel, J. Lerma, J.A. Garcia-Sevilla, Protection by imidazol(ine) drugs and agmatine of glutamate-induced neurotoxicity in cultured cerebellar granule cells through blockade of NMDA receptor, Br. J. Pharmacol. 127 (1999) 1317-1326.

[33] M. Zhu, Y.P. Wang, G. Bissette, Neuroprotective effects of agmatine against cell damage caused by glucocorticoids in cultures rat hippocampal neurons, Neuroscience 141 (2006) 2019-2027.

[34] E. Galea, S. Regunathan, V. Eliopoulos, D.L. Feinstein, D.J. Reis, Inhibition of mammalian nitric oxide synthases by agmatine, an endogenous polyamine formed by decarboxylation of arginine, Biochem. J. 316 (1996) 247-249.

35] G. Sengul, E. Takci, U.A. Malcok, A. Akar, F. Erdogan, H.H. Kadioglu, I.H. Aydin, A preliminary histopathological study of the effects of agmatine on diffuse brain injury in rats, J. Clin. Neurosci. 15 (2008) 1125-1129.

[36] J.H. Kim, M.A. Yenari, R.G. Giffar, S.W. Cho, K.A. Park, J.E. Lee, Agmatine reduces infarct area in a mouse model of transient focal cerebral ischemia and protects cultured neurons from ischemia-like injury, Exp. Neurol. 189 (2004) 122-130.

[37] M. Moretti, F.C. Matheus, P.A. de Oliveira, V.B. Neis, J. Ben, R. Walz, A.L.S Rodrigues, R.D. Prediger, Role of agmatine in neurodegenerative diseases and epilepsy, Front. Biosci. 6 (2014) 341-359.

[38] Y.Z. Feng, A.E. Halaris, J.E. Piletz, Determination of agmatine in brain and plasma using high-performance liquid chromatography with fluorescence detection, J. Chromatogr. B 691 (1997) 277-286.

[39] T. Uzbay, G. Goktalay, H. Kayir, S.S. Eker, A. Sarandol, S. Oral, L. Buyukuysal, G. Ulusoy, S. Kirli, Increased plasma agmatine levels in patients with schizophrenia, J. Psychiatr. Res. 47 (2013) 1054-1060.

[40] Y. Cai, G. Tang, R. Jaffe, R. Jones, Evaluation of some isolation methods for organomercury determination in soil and fish samples by capillary gas chromatography - atomic fluorescence spectrometry, Int. J. Environ. Anal. Chem. 68 (1997) 331-345.

[41] A. Henning, H. Bakirci, W.M. Nau, Label-free continuous enzyme assays with macrocycle-fluorescent dye complexes, Nat. Methods 4 (2007) 629-632.

[42] A. Kallio, P.P. Mccann, DL-alpha-(difluoromethyl) arginine - a potent enzymeactivated irreversible inhibitor of bacterial arginine decarboxylases, Biochemistry 20 (1981) 3163-3166.

[43] J. Andrell, M.G. Hicks, T. Palmer, E.P. Carpenter, S. Iwata, M.J. Maher, Crystal structure of the acid-induced arginine decarboxylase from Escherichia coli: reversible decamer assembly controls enzyme activity, Biochemistry 48 (2009) 3915-3927. 